\title{
25. PALEOMAGNETIC AND ROCK MAGNETIC PROPERTIES OF JURASSIC QUIET ZONE BASALTS, HOLE 801C
}

\author{
Brian P. Wallick ${ }^{2}$ and Maureen B. Steiner ${ }^{3}$
}

\begin{abstract}
The paleomagnetic and rock magnetic properties of 51 Jurassic basalts from Ocean Drilling Program (ODP) Hole 801C have been examined. Magnetic properties vary with lithologic composition; alkalic rocks and hydrothermally-altered tholeiites are much weaker in intensity and generally contain higher coercivity magnetic components than the older and less-altered tholeiites at the base of the hole. For the entire column, the Jurassic basalts have an average initial natural remanent magnetization (NRM) intensity of approximately $1.24 \mathrm{~A} / \mathrm{m}$ and average median destructive fields (MDF) of $8.31 \mathrm{mT}$. These values and the mean Koenigsberger ratio of 1.7 are very similar to results obtained for Jurassic basalts from the Atlantic (DSDP Leg 76). The similarities suggest that the basalts of both sites and their remanence characteristics are representative of Jurassic oceanic crust.

The most profound discovery in these samples was the presence of 5 inclination zones, each showing consistent positive (or negative) polarity opposite the overlying and underlying polarity bands. We interpret these to represent a record of change in polarity of the Earth's magnetic field and, because of the large number over such a short interval $(60 \mathrm{~m})$ of crust, we assert that the rapid change in polarity during the Jurassic is the probable reason behind the origin of the Jurassic Quiet Zone.
\end{abstract}

\section{INTRODUCTION}

Several attempts have been made in the past to reach Jurassic oceanic crust within the region referred to as the Jurassic Quiet Zone in order to examine the magnetic character of samples of that age. Sites $198\left(25.8^{\circ} \mathrm{N}, 154.6^{\circ} \mathrm{E}\right)$ and $199\left(13.5^{\circ} \mathrm{N}, 156.2^{\circ} \mathrm{E}\right)$ were terminated due to drilling complications (Heezen, MacGregor, et al., 1973) while nearby Site $585\left(13.5^{\circ} \mathrm{N}, 156.8^{\circ} \mathrm{E}\right)$ was stopped in a thickerthan-expected sequence of Lower Cretaceous turbidites (Shipboard Scientific Party, 1985a). Most disappointing was the recovery of a thick sequence of Cretaceous intrusive and extrusive rocks from Hole $462 \mathrm{~A}\left(17^{\circ} 14.5^{\prime} \mathrm{N}, 165^{\circ} 1.9^{\prime} \mathrm{E}\right)$ in the Nauru basin, a site that lies beyond a magnetic anomaly correlated with chron M26, thus indicating a Late Jurassic age (Shipboard Scientific Party, 1981). Further drilling of Hole $462 \mathrm{~A}$ on Leg 89 yielded similar results (Shipboard Scientific Party, 1985b). Even on the present leg, both Site 800 $\left(21^{\circ} 55.4^{\prime} \mathrm{N}, 152^{\circ} 19.4^{\prime} \mathrm{E}\right)$ and Site $802\left(12^{\circ} 5.8^{\prime} \mathrm{N}, 153^{\circ} 12.6^{\prime} \mathrm{E}\right)$ were terminated in Cretaceous volcanic rocks (Lancelot, Larson, et al., 1990). The third site, Site $801\left(18^{\circ} 38.6^{\prime} \mathrm{N}, 156^{\circ} 21.6^{\prime} \mathrm{E}\right)$, however, reached its intended target and finally laid to rest any doubts that the magnetic smooth zone in this region did hold, at least in part, remnants of the Middle and Late Jurassic Pacific plate.

While remote sensing studies of variations of the geomagnetic field will continue to play a major role in our understanding of crustal movements and development, they can play only a partial role in our understanding of the origins of the Jurassic Quiet Zone. Only analyses of samples collected directly from the Jurassic Quiet Zone can provide answers to the questions concerning the nature of the region. Hole $801 \mathrm{C}$ provides the first recovery of basement samples from the Jurassic Quiet Zone in the western central Pacific. The purpose of this study is to report paleomagnetic and rock magnetic data for this site and, where possible, to assess various theories on the origin of the Jurassic Quiet Zone within the context of these measurements.

\footnotetext{
' Larson, R. L., Lancelot, Y., et al., 1992. Proc. ODP. Sci. Results, 129: College Station. TX (Ocean Drilling Program).

${ }^{2}$ Department of Earth and Atmospheric Science, Purdue University, West Lafayette. IN 47907, U.S.A.

${ }^{3}$ Department of Geology and Geophysics, University of Wyoming, Laramie, WY 82071, U.S.A.
}

\section{THE JURASSIC QUIET ZONE}

The existence of a magnetic smooth zone in the western central Pacific has been known for some time. This smooth zone, commonly referred to as the Jurassic Quiet Zone, is a region bounded by the M25 magnetic lineation (Larson, 1976) and has been demonstrated as corresponding in age to quiet zones in the Atlantic Ocean off North Africa and the east coast of the United States (Larson and Lowrie, 1972). While there has been some success correlating anomalies within the Jurassic Quiet Zone of the Pacific, the anomalies, where present, can best be characterized as having extremely low amplitudes relative to those of anomaly M22 and younger (Cande et al., 1978). Handschumacher et al. (1988) extended linear magnetic anomaly correlations into the Jurassic Quiet Zone back to M38; the age of the earliest lineation was projected using the Harland et al. (1982) scale as approximately $172 \mathrm{Ma}$ (Bajocian) or using the DNAG scale (Kent and Gradstein, 1978) as about $165 \mathrm{Ma}$ (Callovian). Most of the interior Jurassic Quiet Zone, however, shows no correlatable anomalies and the magnetic signal appears to consist largely of random noise.

A variety of mechanisms have been proposed by various authors to explain the Jurassic Quiet Zone. Pitman et al. (1968) suggested that the magnetic properties of rocks of the Cretaceous quiet zone may have changed owing to diagenetic processes, a scenario that can easily be extended to include the Jurassic Quiet Zone. Indeed, the process of hydrothermal alteration of source basalts has been implied by several authors as a possible cause for the Jurassic Quiet Zone (Vogt et al., 1971; Taylor et al., 1968). Houtz and Ewing (1976) recorded a thickening of low velocity layer $2 \mathrm{~A}$ crustal rocks associated with the Jurassic Quiet Zone and presumed there might be some connection to the change in magnetic properties therein. An increase in viscous magnetizations with age has been invoked by others (e.g. Lowrie, 1973) such that the original magnetizations are completely masked in present-day normal polarity overprint. Blakely (1983) has called on a progressive demagnetization of the source layer with time. A common characteristic of these theories is the notion that Jurassic basalts have crossed an age threshold, beyond which the magnetic signal is diminished.

A popular theory was that the Jurassic Quiet Zone was caused by an interval of constant magnetic polarity during the Early and Middle 
Jurassic which produced a magnetic quiet zone similar to that of the middle Cretaceous Long Normal (Heirtzler et al., 1968). Several authors (Emery, 1970; Poehls et al., 1973; Hayes and Rabinowitz, 1975) proposed this explanation, and a corresponding long normal polarity interval was included in the magnetic polarity time scales of Larson and Pitman (1972) and Larson and Hilde (1975). Related to this long normal polarity hypothesis, a reduced strength of the Earth's dipole field at the time of emplacement of the Quiet Zone basalts was also viewed as a possibility (Vogt et al., 1971; Larson and Hilde, 1975; Cande et al., 1978). Gradual field strength reduction also helped to explain why the boundary to the Quiet Zone was not abrupt but rather occurred as a gradual reduction in magnetic anomaly amplitude between M22 and M25 (Larson and Pitman, 1972).

There have been suggestions that variations in tectonic style have caused the unusual magnetic signature or possibly the erasure of a preexisting signal. The Jurassic Quiet Zone of the Atlantic coastal areas was once thought to be a separate ocean basin which was subsequently rifted apart (Drake et al., 1968). While this scenario is unlikely, especially in the present case, several tectonic problems are envisioned in the growth of a small triangular-shape Pacific plate that could be contributing factors in the magnetic quiescence of the region.

Steiner and Ogg (1987) and Handschumacher et al. (1988) have argued that the Jurassic Quiet Zone basalts were emplaced during a period of extremely rapid reversals. It is reasoned that the magnetic signatures of closely spaced, superimposed anomalies would essentially cancel, resulting in zero signal at the surface. This interpretation is consistent with the results obtained in land sections of Bathonian and Callovian sediments by Steiner et al. (1988), Channell et al. (1990), and Ogg et al. (1991) and also with the low-amplitude correlatable anomalies that have been discovered within the traditional M25 boundary of the Jurassic Quiet Zone.

\section{BASEMENT STRATIGRAPHY}

Site 801 basement recovery can be divided into three distinct segments (Fig. 1). The lowest segment has a tholeiitic composition and consists largely of thin flows and pillow basalts corresponding to cores 801C-5R through 801C-12R (Shipboard Scientific Party, 1990; Castillo et al., 1990; Floyd et al., 1991). This interval is capped by a hydrothermal deposit consisting largely of goethite and replacement quartz (Core $801 \mathrm{C}-4 \mathrm{R}$ ). Deposition of the hydrothermal layer directly altered the uppermost tholeiitic basalts (Core $801 \mathrm{C}-5 \mathrm{R}$ ) by infilling of pores and cracks with hydrothermal precipitates and by brecciation of existing flows (Floyd et al., 1991). The uppermost and youngest portion of basement consists of highly altered flows and/or sills of alkalic basalt composition (Castillo et al., 1990; Floyd et al., 1991). These basalts are overlain by red radiolarites and claystones that exhibit both basal chaotic slumping and steeply dipping strata with dips averaging approximately $20^{\circ}$ as estimated from Formation MicroScanner (FMS) images (Molinie and Ogg, this volume) and descriptions of recovered sediments (Shipboard Scientific Party, 1990).

\section{METHODS}

The natural remanent magnetization (NRM) of the alkali olivine basalts of Site $801 \mathrm{~B}$ have a $\log$ mean intensity of $1.65 \times 10^{-2} \mathrm{~A} / \mathrm{m}$. Owing to this low intensity and especially the limited vertical extent of the alkali olivine basalt suite (approximately $50 \mathrm{~m}$ ), these rocks are not considered to be a significant contributor to the crustal magnetic signature measured at the surface. This paper will therefore concentrate on the properties of the tholeiitic basalts, which we equate with normal oceanic crust and consider as more likely representative of Jurassic Quiet Zone basement.

Sampling intervals were based largely on discrete flow units identified by the shipboard igneous petrologists (Shipboard Scientific Party, 1990) and are graphically illustrated in Figure 1. Individual sampling sites were selected largely on the basis of grain size, with

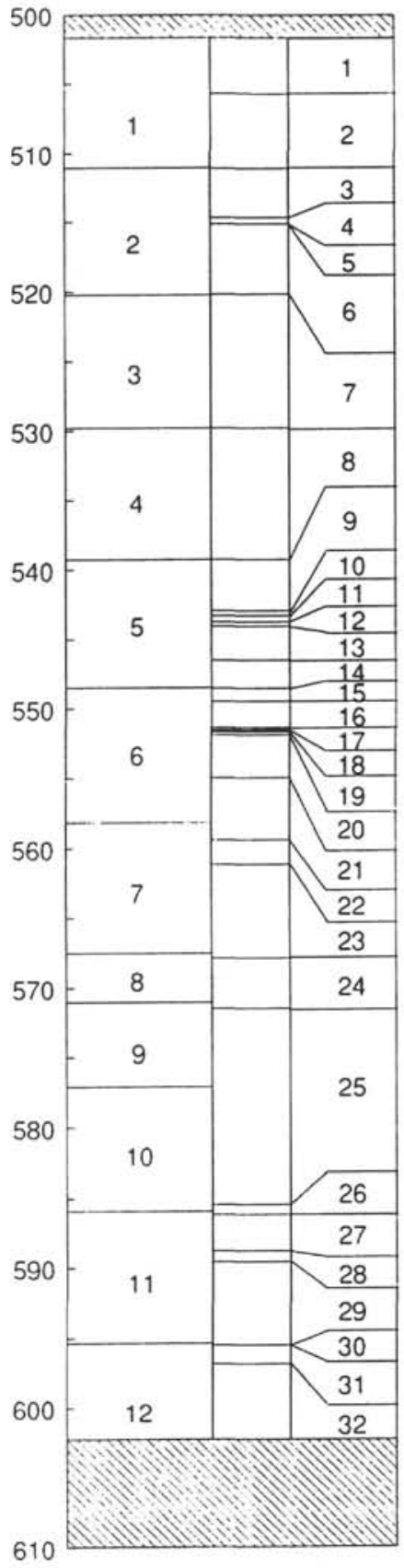

Figure 1. Column showing the generalized stratigraphic relationships between the three major basement components. The left hand column shows the ODP core designation for Hole 801C, the center column shows the actual thickness distribution of shipboard-defined igneous flow units, and the right hand column shows the numbering scheme for the flow units.

finer-grained rocks taking precedence over their coarse-grained counterparts. In addition, we attempted to select samples in which the length exceeded the inside diameter of the core liner in order to largely eliminate problems of interpreting samples that had become inverted during the coring process. While the stratigraphic "up" of Sample $801 \mathrm{C}-8 \mathrm{R}-2,18 \mathrm{~cm}$, is unknown, the true orientation of all other samples is accurately known. Flow units too small for multiple sampling were not sampled. Samples consisted of $2.5 \mathrm{~cm}$ diameter minicores with axes perpendicular to the axis of the main drillcore. All samples were scribed prior to drilling with an arrow designating 
the stratigraphic "up" direction; this orientation mark was scribed parallel to the edge of the longest side of the selected core piece. We analyzed a total of 51 samples from Hole 801C.

A Schonstedt SSM-1 spinner magnetometer was utilized for NRM and demagnetization measurements; all samples were measured at six spin orientations in order to minimize measurement error. Samples too weak for accurate spinner magnetometer measurements were measured with a $2 \mathrm{G}$ two-axis cryogenic magnetometer. For all samples, demagnetization was accomplished with a Schonsted GSD-1 single-axis alternating field (AF) demagnetizer with incremental steps carried from $2.5 \mathrm{mT}$ to a maximum of $60 \mathrm{mT}$. The majority of samples were reduced to less than $10 \%$ of their initial magnetization and most were taken to a maximum demagnetization level of $60 \mathrm{mT}$. Samples were not taken to higher demagnetization levels due to the possibility of acquisition of anhysteretic remenant magnetizations
(ARM) at levels above $60 \mathrm{mT}$. Susceptibility was measured using a Bison MS-3 magnetic susceptibility bridge. Hysteresis parameters were acquired using the $2 \mathrm{G}$ induction coil magnetometer, as described by Shive and Goodman (1990). The results for all analyses are given in Table 1.

\section{RESULTS}

\section{Natural Remanent Magnetization}

The initial natural remanent magnetization (NRM) intensity for Site $801 \mathrm{C}$ samples varies with both depth and igneous flow unit. With the exception of the pillowed unit from Cores $801 \mathrm{C}-11 \mathrm{R}-3,60 \mathrm{~cm}$, to $12 \mathrm{R}-1,150 \mathrm{~cm}$ (flow units 29 through 31 ), the overall trend appears to be a general increase in intensity with increasing depth (Fig. 2). Highest values for NRM intensity are found in the tholeiitic basalt
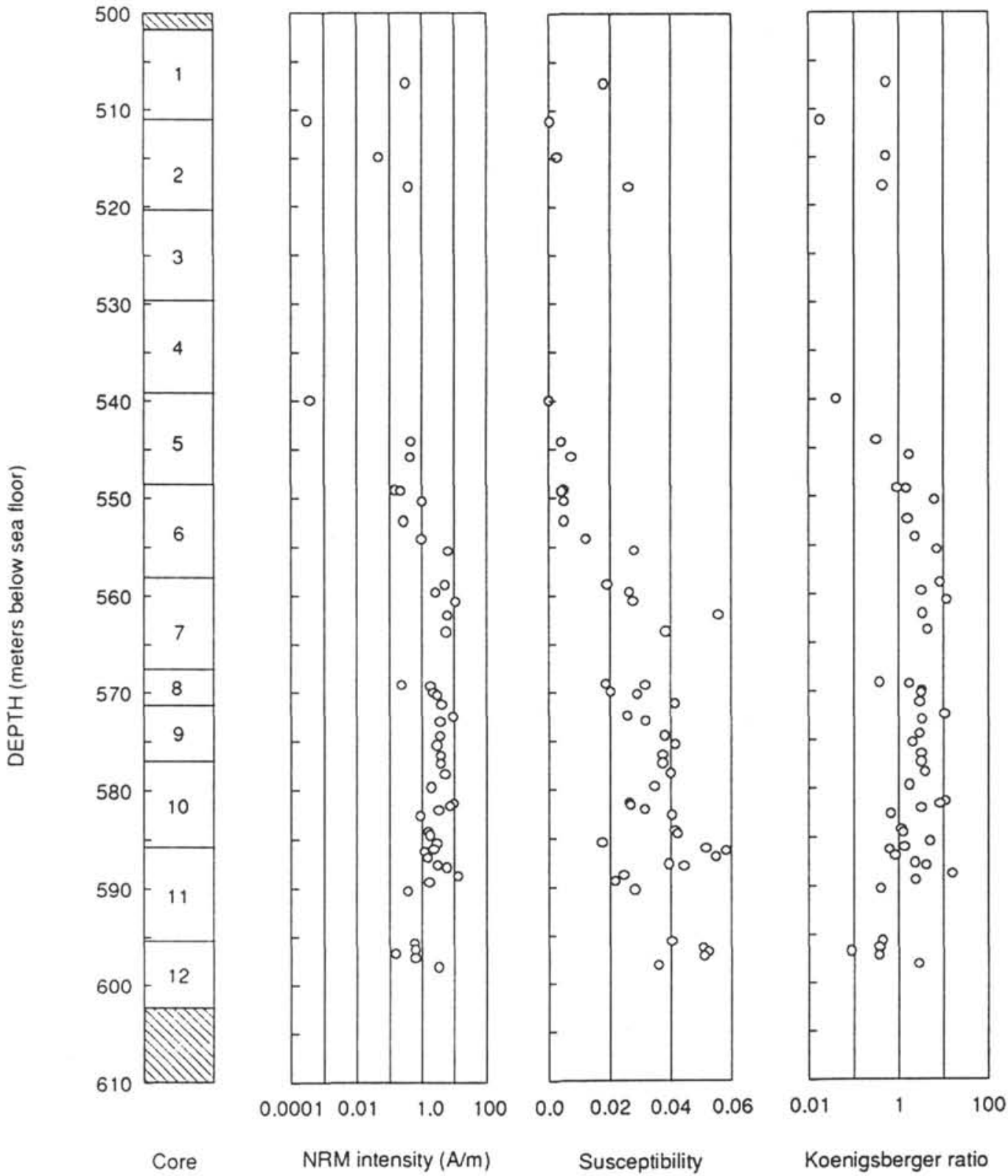

Figure 2. Depth distribution of NRM intensity, susceptibility, and Koenigsberger ratio for Hole $801 \mathrm{C}$ basalt samples. Intensity and Koenigsberger ratios are given in log scale while the susceptibility is shown on a linear scale. The column at the left shows the core designations for the hole. 
samples from Cores $801 \mathrm{C}-6 \mathrm{R}-4$ through $801 \mathrm{C}-12 \mathrm{R}-2$. Intensity values for samples of this interval ranged from between 0.26 and $13.27 \mathrm{~A} / \mathrm{m}$ with a weighted $\log$ mean of $2.3 \mathrm{~A} / \mathrm{m}$.

Low values of NRM intensity occur in the alkali olivine basalts and rocks of Cores $801 \mathrm{C}-5 \mathrm{R}-1$ through $6 \mathrm{R}-1$; values as low as $3.7 \times 10^{-4} \mathrm{~A} / \mathrm{m}$ are consistent with the moderate to high alteration seen in these rocks, particularly those occurring just beneath and associated with the hydrothermal layer (Core 801C-5R). NRM intensity levels of the alkali olivine basalts (Cores $801 \mathrm{C}-1 \mathrm{R}$ through $3 \mathrm{R}$ ) are similar to those seen in pilot studies of $801 \mathrm{~B}$ basalts at the same approximate level.

\section{Susceptibility and Koenigsberger Ratio}

Susceptibility $(\chi)$ shows a marked increase in value corresponding to the base of flow unit 20 (Core 6R-4) and coincident with the rise seen in NRM intensity at this same level (Fig. 2). This factor of ten increase is likely a byproduct of the more intense alteration of the alkali olivine basalts and the hydrothermal alteration of the uppermost portions of the tholeiitic basalts. Other than this major change, which occurs between sections 3 and 4 of core 801C-6R, susceptibility values range widely and probably reflect the variation in grain size and volume distribution of titanomagnetite from one unit to the next. The susceptibility values range from a low of 2.65 $\times 10^{-4}$ in the alkali olivine basalts to a high of $5.81 \times 10^{-2}$ in flow unit 27 of the tholeiitic basalts.

Koenigsberger ratios $(\mathrm{Q})$ were calculated for all samples (Table 1). $\mathrm{Q}$ is the ratio of remanent to induced magnetization and therefore gives a relative measure of the contribution of these magnetizations to the total magnetization of the sample. Samples with Koenigsberger ratios greater than 1 are presumed to be dominated by primary remanence and are least likely to be dominated by viscous or secondary components. The induced magnetization is the product of the measured susceptibility and of the value of the total Earth's field at the sampling locale; the value for the Earth's field at the sampling location at a depth of $6300 \mathrm{~m}$ below sea level is calculated at $35,097 \mathrm{nT}$. With the exception of the lowermost pillow lava Samples $11 \mathrm{R}-3,140 \mathrm{~cm}$ through $12 \mathrm{R}-1$ (flow units 29-31), the tholeiite section has $\mathrm{Q}$ ratios generally greater than 1 and is therefore apparently dominated by remanence.

\section{Hysteresis Parameters}

The measurement of hysteresis parameters yields two particularly useful rock magnetic properties: saturation magnetization and coercive field strength. The magnetization of a given sample will continue to increase with increasing field strength until the domains of all magnetic minerals are aligned with the applied field. Thus, the saturation magnetization $\left(J_{s}\right)$ is proportional to the volume of titanomagnetite series magnetic material in a sample and provides a relative measure of that volume. Figure 3 shows the variation of $\mathrm{J}_{\mathrm{s}}$ with depth for samples from Cores $801 \mathrm{C}-6 \mathrm{R}-2$ to $12 \mathrm{R}-2$. Lowest values for $\mathrm{J}_{\mathrm{s}}$ are found in the uppermost tholeiites of Cores $801 \mathrm{C}-6 \mathrm{R}-2$ through $6 \mathrm{R}-4$ (flow units 16 and 20). The highest values (up to $4333 \mathrm{~A} / \mathrm{m}$ ) are associated with Core Samples $801 \mathrm{C}-10 \mathrm{R}-6,95 \mathrm{~cm}$ through 11R-2 and Core 12R-1 (flow units 26-27 and 31) and therefore might indicate relatively large amounts of magnetic minerals for rocks of those units. Oddly, core 12R-1 (flow unit 31), part of the lowermost pillow basalt complex, has anomalously low values of both NRM intensity and Q; therefore, these cannot be attributed to an overall decrease in magnetic material.

The coercive field $\left(\mathrm{H}_{\mathrm{c}}\right)$ is the field required to overcome the internal energy barriers associated with domain walls and allow the alignment of the individual spin axes with the applied field. In essence, this is a measure of the stability of sample remanence and the ability of that sample to acquire an induced remanence. These basalts display extremely low values for the coercive field, in many cases less than $5 \mathrm{mT}$ (Fig. 3). A comparison of $\mathrm{H}_{\mathrm{c}}$ values with those of the median destructive field (MDF) for each sample (Table 1) shows good correlation between these two parameters and therefore suggests the reliability of the samples for paleomagnetic studies (Furuta, 1983). The low values of $\mathrm{H}_{\mathrm{c}}$ and MDF in these rocks are consistent with the presence of multidomain titanomagnetite grains.

\section{Stable Inclination}

Stable inclinations for Site 801C samples were determined using stereographic projections of stepwise demagnetization vectors in combination with orthogonal axis plots. A complete listing of individual results of stepwise AF demagnetization are provided in the Appendix. Stable inclination vectors were defined using the least squares method of Kirschvink (1980). The analysis of the data revealed three basic types of sample decay and allowed an assessment of the quality of resultant characteristic directions. The most common type of demagnetization pattern is a univectorial decay toward the origin in orthogonal-axis plots and associated stable values of declination and inclination in stereographic projection (Fig. 4). The majority of samples analyzed are characterized by this directionally stable behavior. At AF levels above approximately $40 \mathrm{mT}$, some samples show additional vector movements (Fig. 4) which deviate away from the trend to the origin. There is a tendency for this movement to be toward shallower inclinations, but the opposite was also observed. It is possible that these movements may represent the presence of another component in the NRM of the samples. However, we believe that these departures represent the acquisition of anhysteretic remanence (ARM) or a viscous magnetization acquired between demagnetization and measurement, and made more prominent by the weak intensities of the samples after high field demagnetization.

The second group (Fig. 5) is characterized by samples whose stable directions are less well-defined. Subsequent to an initial trend toward the origin during the low field steps of AF demagnetization, sample directions begin to "wander" while at still relatively low demagnetization levels $(20-30 \mathrm{mT})$. Commonly, three or more vectors can be identified in the demagnetization trends of these samples. This behavior may reflect acquisition of a high temperature VRM during emplacement of the alkali olivine basalts, or may be the result of the apparently rapid changes of polarity of the geomagnetic field during emplacement of these basalts.

A third pattern is a complete randomness in sample behavior throughout the entire demagnetization process (Fig. 6). The sample illustrated shows neither a well-defined stable endpoint, nor, in some instances, a definite positive or negative value. The remanences of these samples are ignored in further analysis.

A comparison of NRM and characteristic inclinations vs. depth shows that characteristic directions are considerably more uniform after progressive AF demagnetization (Fig. 7). Also evident are a number of changes in sign, which are largely duplicated in both the NRM and stable inclination measurements.

Multiple samples from individual flow units were arithmetically averaged and combined statistically with single-sample, single-flow unit data using the method devised by Kono (1980) for averaging mean inclinations derived from azimuthally-unoriented cores. The statistics were compiled for each polarity group and for the combined data. The results indicate a mean inclination of $-34.8^{\circ} \pm 9.5^{\circ}(k=14.6)$ for all negative polarity flow units and a mean inclination of $+27.1^{\circ} \pm$ $6.9^{\circ}(k=22.5)$ for all positive polarity flow units. The inclination from combined data, including the mixed polarity set of flow units 24 and 26 is $30.9^{\circ} \pm 4.8^{\circ}(k=19.3)$. Inclinations and demagnetization behavior seen in overlying sediments (Steiner and Wallick, this volume) suggest a southern hemisphere origin for these basalts.

Dips of $20^{\circ}$ to the southwest are observed in FMS images of the overlying Callovian sediments (Molinie and Ogg, this volume) with drillstring deviations not exceeding more than $2.5^{\circ}$ (Shipboard Sci- 

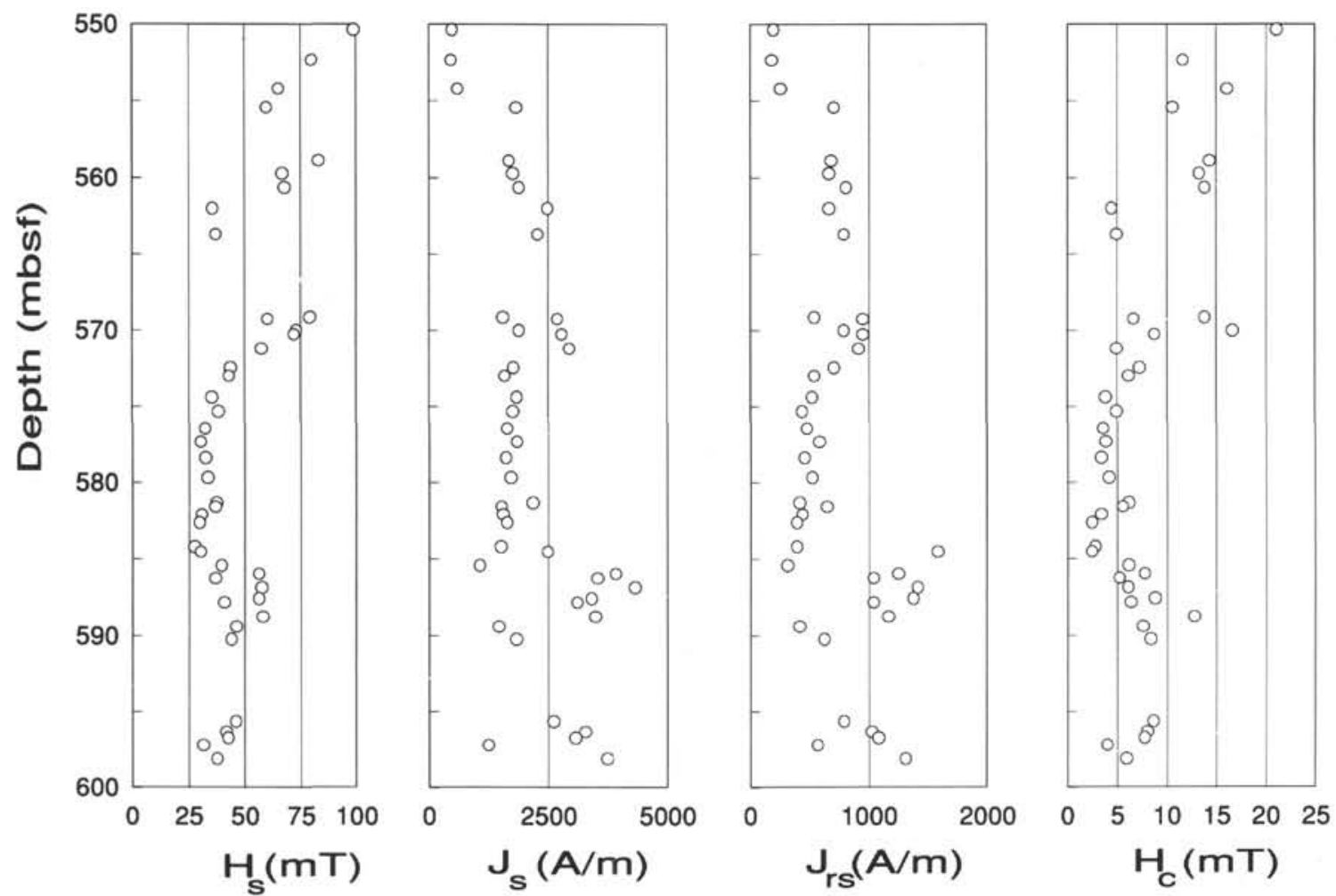

Figure 3. Hysteresis parameters for the tholeiitic basalts of Hole 801C. $\mathrm{H}_{\mathrm{s}}$ is the value of the saturation field and $\mathrm{H}_{\mathrm{c}}$ is the value of the coercive field, both in $\mathrm{mT}$. $\mathrm{J}_{\mathrm{s}}$ is the saturation magnetization and $\mathrm{J}_{\mathrm{rs}}$ is the saturation remanence both in $\mathrm{A} / \mathrm{m}$.

entific Party, 1990). Therefore it is possible that the entire volcanic pile has been subjected to a post-Callovian rotation of approximately $20^{\circ}$. The $20^{\circ}$ southwest sediment dip may be applied as a correction to the basalt inclinations by assuming that Jurassic "North" was not significantly rotated from present North declination (the "Stealth Plate" hypothesis of Larson and Sager, this volume). The component of southwest dip $\left(14^{\circ}\right)$ is subtracted from the mean inclination $\left(30.9^{\circ}\right)$ of the combined flows. The resulting "dip-corrected" inclination of $17^{\circ} \mathrm{implies}$ a paleolatitude of $9^{\circ} \mathrm{S}$ which is significantly more shallow than the $16.6^{\circ} \mathrm{S}$ paleolatitude as calculated from the uncorrected $30.9^{\circ}$ mean inclination.

It is possible that the dip of the sediments is wholly or partly unrelated to the attitude of the basement basalts. The sediments lie stratigraphically atop the off-axis alkali basalt complex, which is, in turn, separated from the tholeiites (from which the inclinations were measured) by a $10 \mathrm{~m}$ thick hydrothermal zone. Several possibilities cannot be excluded at present: (1) that the hydrothermal deposits acted as a décollement surface when sediment tilting occurred; (2) that the sediments are a slump block formed in the rift valley of the time; or (3) that some of the alkali olivine basalt complex is intrusive and that the tilt is related to that activity.

At this point, we note the proximity of the "corrected" $9^{\circ} \mathrm{S}$ paleolatitude estimate from the Bathonian basalts to that of $6^{\circ} \mathrm{S}$ approximation derived from the overlying Callovian sediments (Steiner and Wallick, this volume) while further noting that the paleolatitude for the Bathonian basalts may be as high $17^{\circ} \mathrm{S}$.

\section{DISCUSSION}

\section{Polarity}

A notable aspect of the characteristic magnetizations of these rocks is the change in sign of inclinations that appears to correspond to boundaries between shipboard-defined volcanic flow units. If these represent changes in the Earth's magnetic field, this would have ramifications not only on the nature of the Jurassic Quiet Zone but on the magnetic structure of the oceanic crust as well.

Changes in polarity have been previously observed in oceanic basalts, with several possible explanations:

1. Inadvertent inversion of a sample, either within the drill string or through operator handling, is a common source of ambiguity. In the present work, one such Sample ( $801 \mathrm{C}-8 \mathrm{R}-2,18 \mathrm{~cm}$ ) has been identified and those results are treated accordingly. However, as previously noted, our samples were generally taken from core pieces in which intra-core rotation would not be possible (i.e., the length of the core piece exceeds the diameter of the core liner). Indeed, long core pieces were preferred for sampling and for purposes of marking accurate upcore orientations on individual pieces. The tendency for the observed polarity groups to be large and to cross core boundaries in the present study (for example negative polarity for the latter part of Core $11 \mathrm{R}$ continuing through to Core $12 \mathrm{R}$ ) renders accidental inversion unlikely.

2. Discreet block rotations or inversion of individual blocks of cooled lava within the volcanic pile may well have occurred during subsequent rifting and lava emplacements, particularly in light of the apparent late tectonic movements associated with the area. However, block rotations seem unlikely for our suite owing to the near antipodal nature of the inclinations measured for both polarity groups. It would be fortuitous for several independent blocks to have been rotated to yield directly mirrored inclinations.

3. Secular variation coupled with the near equatorial emplacement of these basalts may account for the apparent polarity changes. Although the degree of paleosecular variation for the Jurassic is not known, an estimation of $13.4^{\circ}$ (Irving and Pullaiah, 1976) may be made for the predicted $9^{\circ} \mathrm{S}$ latitude of formation. Values of $k$ for the positive and negative polarity groups give circular standard deviation values of $17.1^{\circ}$ and $21.2^{\circ}$, respectively; each of these values then exceeds 


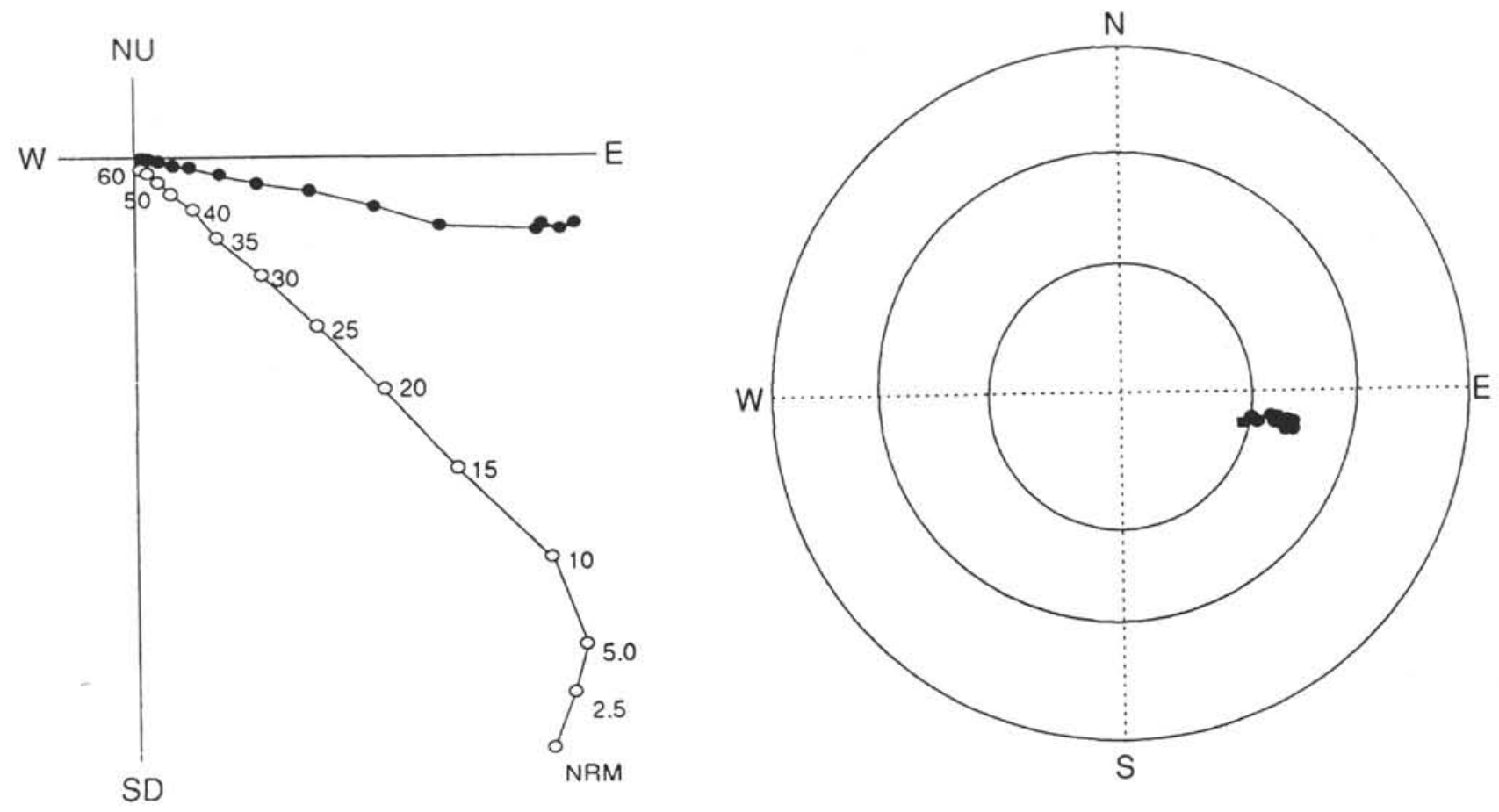

Figure 4. Vector projection diagram and stereographic projection of successive demagnetization steps on Sample $801 \mathrm{C}-7 \mathrm{R}-1,83 \mathrm{~cm}$, illustrating the typical univectorial decay seen in the majority of the samples analyzed. Open circles refer to inclination while closed circles represent declination; squares denote the initial NRM measurements on stereographic projections. Complete demagnetization data are provided in the Appendix.

the limits of the estimated $13.4^{\circ}$ of secular variation. At the "corrected" paleolatitude of $9^{\circ} \mathrm{S}$, paleosecular variation would have to be extraordinarily large (in excess of $50^{\circ}$ ) to account for the observed distinct separation of the polarity groups.

4. Recorded reversals of the Earth's magnetic field during extrusion of the volcanic succession have previously been noted in other ocean crust drilling sites (e.g., Johnson, 1978; Hall and Robinson, 1979). This explanation is preferred for the Site 801 basalts.

We consider the polarity determinations (Table 1) and the interpretion of the vertical sequence of polarity changes (Fig. 7) to represent a record of geomagnetic field reversals during the latter part of the Bathonian. Assignment of normal vs. reversed polarity in these samples is based on paleomagnetic observations in the overlying sediments (Steiner and Wallick, this volume) that indicate deposition was in the southern hemisphere. Designations N (R), NP (RP), and U (Table 1) refer to the three types of demagnetization response observed in the samples; $U$ refers to samples with unknown polarity, NP (RP) represents samples with 3 to 4 univectorial decay points, and $\mathrm{N}$ (R) refers to samples exhibiting univectorial decay to the origin of orthogonal axis plots.

Clearly, the interpretation of multiple polarity is not without problems. First, the remanence appears to be largely carried by low coercivity components as indicated by the low coercive fields and MDFs associated with the majority of the samples in this study. However, univectorial decay is exhibited by the majority of samples suggesting that the characteristic directions represent a primary magnetization. The second problem is the frequency of polarity reversals recognized in this sequence. We have identified 5 polarity reversals within less than $60 \mathrm{~m}$ of basalt core. These do not include isolated single sample polarity changes from single flow units, as in the reversed sample from Core 1R-4; nor do these include ambiguous results as noted from flow units 24 and 26, which, if included in the polarity column, suggest an even more rapid reversal rate than already interpreted. This interpretation of multiple polarity goes to the very heart of the origin of the Jurassic Quiet Zone.

\section{Significance for the Jurassic Quiet Zone}

The paleomagnetic properties of the basalts of this hole (NRM intensity, MDF, demagnetization behavior) are remarkably similar to those observed in the Upper Jurassic basalts from DSDP Leg 76 (Shipboard Scientific Party, 1983; Steiner, 1983; Testarmata and Gose, 1983). The log mean initial NRM intensity for Hole 801C basalts is $1.24 \mathrm{~A} / \mathrm{m}$ and includes the low intensity rocks from the alkalic suite and the hydrothermally altered tholeiitic rocks of Cores $801 \mathrm{C}-5 \mathrm{R}$ and $6 \mathrm{R}$. This value is comparable to the arithmetic mean calculated for DSDP Leg 76 basalts of $3.6 \mathrm{~A} / \mathrm{m}$ (Steiner, 1983) and, in general, for other oceanic basalts (e.g., Furuta and Levi, 1983). Similarly, the log mean MDF is calculated to be $8.31 \mathrm{mT}$ for the Hole $801 \mathrm{C}$ basalts as compared to $8.9 \mathrm{mT}$ for Leg 76 basalts (Steiner, 1983). The mean value of 3.1 for Q in the DSDP Leg 76 basalts (Testarmata and Gose, 1983), while slightly higher than the mean of $\mathrm{Q}=1.7$ for Hole $801 \mathrm{C}$ basalts, still suggests roughly comparable susceptibilities. Ogg and Testarmata (Shipboard Scientific Party, 1983) and Steiner (1983) have examined the aspects of viscous behavior as a causative agent for the Jurassic Quiet Zone and concluded little effect from VRM in their samples; we have not properly addressed this problem to date. Finally, the demagnetization behavior of Leg 76 basalts showing "excellent directional stability . . . in striking contrast to the low coercivity ..." (Steiner, 1983) is further similar to the rocks of the present study. While the rocks of these two sites are separated in age by 6-10 m.y., we still consider the similarities to be more than coincidence and that these characteristics of Hole $801 \mathrm{C}$ basalts are characteristic of Jurassic oceanic crust.

The question of continual change in magnetic properties with increasing age has, for the most part, been answered in the above viscosity studies; these studies show that for basalts of like age, viscous components do not appear to be significantly greater than those measured in younger basalts. In addition, petrographic analysis has yielded no evidence of unusual submarine alteration. In fact, " . . . there is little evidence for a simple progressive alteration of the oceanic crust with time or crustal 'aging'" (Floyd et al., 1991). Wallick et al. (this volume) 


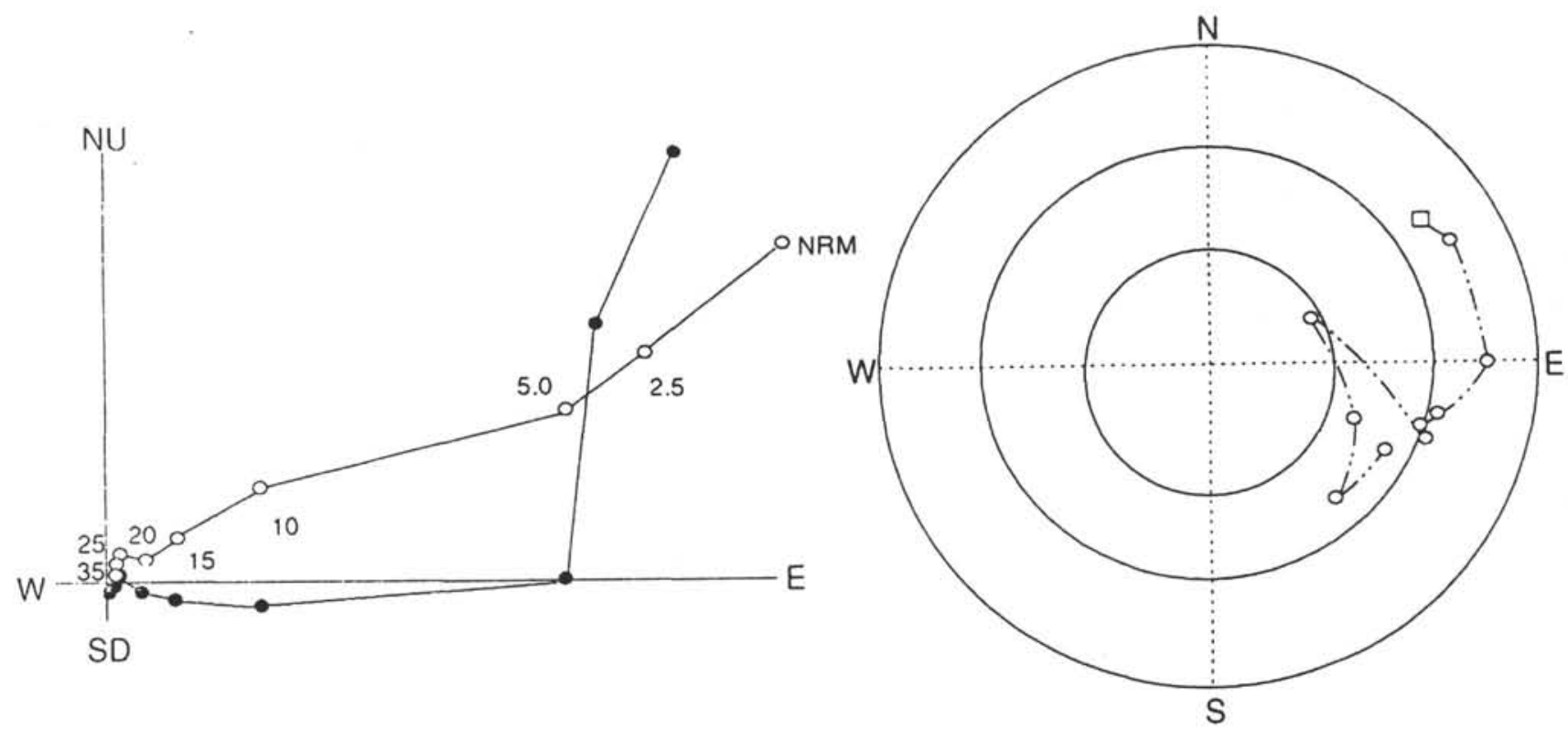

Figure 5. Vector projection diagram and stereographic projection of stepwise demagnetization of Sample 801C-12R-1, $107 \mathrm{~cm}$, illustrating three-step stable decay to the origin preceded by removal of significant secondary component. Conventions are the same as in Figure 4.

came to the same conclusion from velocity studies suggesting that the distinct change in velocity seen in the study was the result of higher porosity in the upper unit and compositional differences between the two basalt types rather than any age-related phenomenon as was suggested by Houtz and Ewing (1976).

Clearly, too, our results further counter the concept of a period of long normal polarity in the Jurassic. This theory appears to be disproved not only on the basis of this study but those of Handschumacher et al. (1988) and land studies of Callovian and Bathonian sediment paleomagnetism as well (Steiner et al., 1988; Channell et al., 1990; Ogg et al., 1991). Indeed, the present study reaches the same conclusion as these previous studies: that rapid reversals in the middle Jurassic are largely responsible for the magnetic quiescence of the Jurassic Quiet Zone.

This discussion and the following conclusions should be tempered by three points that have not been stressed here. First, many of the results, particularly those in connection with MDF and $\mathrm{H}_{\mathrm{c}}$, could be strengthened by the inclusion of petrographic analysis using reflected light techniques to resolve questions regarding the nature of the magnetic carrier. In addition, Curie temperature analysis would be useful in determining the oxidation state of the minerals in question. Second, these samples must be monitored for acquisition of viscous remanent magnetizations. Logging of Hole $801 \mathrm{C}$ would help to determine whether or not the initial NRM measurements listed here reflect true in situ values. Finally, it should be understood that while Site 801 does represent the only documented Jurassic crust recovered from the Pacific basin, it nonetheless represents a single sampling of a very large area.

\section{CONCLUSIONS}

1. The tholeiitic basalts have NRM intensities that are neither significantly weaker nor stronger than those found in most oceanic crustal basalts. The alkali olivine basalts comprising the uppermost flows of the Jurassic basement and the hydrothermally altered basalts immediately beneath the hydrothermal layer lack sufficient vertical extent and intensity to have any effect on surface magnetic readings.
2. Low MDF and coercive field values suggest that these samples are dominated by low coercivity magnetic components. Nonetheless, univectorial decay observed in the majority of these samples indicates that the characteristic direction is carried by low coercivity components; this characteristic remanence is interpreted as primary.

3. Stable inclinations measured for the tholeite section record groupings of positive and negative values. The mean inclination for the positive group is $27.1^{\circ} \pm 6.9^{\circ}$ while that of the negative group is $34.8^{\circ} \pm 6.9$. A tilt-corrected paleolatitude for the combined units based on the observed sediment bedding is estimated at $9^{\circ} \mathrm{S}$.

4. The inclination polarity largely corresponds to igneous flow unit boundaries and is interpreted as a manifestation of geomagnetic polarity zones; five such zones occur within the tholeiite section. The observation of these 5 polarity zones over such a short segment of the crust suggests that the earth's magnetic field was experiencing rapid changes in polarity, an observation that has been corroborated in sediment paleomagnetic analyses. This period of rapid reversals currently offers the best explanation for the incoherent magnetic signals within the Jurassic Quiet Zone.

\section{ACKNOWLEDGMENTS}

This work benefited greatly from the insights and critical reviews of Jim Ogg, H. P. Johnson, and J. A. Tarduno. In addition, conversations with and encouragements from Jim Ogg, Pat Castillo, Peter Floyd, and Roger Larson are greatly appreciated.

\section{REFERENCES}

Blakely, R. J., 1983. Statistical averaging of marine magnetic anomalies and the aging of oceanic crust. J. Geophys. Res., 88:2289-2296.

Cande, S. C., Larson, R. L., and LaBrecque, J. L., 1978. Magnetic lineations in the Pacific Jurassic quiet zone. Earth Planet. Sci. Lett., 41:434-440.

Castillo, P. R., Floyd, P. A., and Leg 129 Shipboard Scientific Party, 1990. Petrology and $\mathrm{Nd}-\mathrm{Pb}$ isotope geochemistry of the oldest Pacific crust recently discovered in the Western Pacific: preliminary results. Eos, 71:1672.

Drake, C. L., Ewing, J. I., and Stockard, H., 1968. The continental margin of the eastern United States. Can. J. Earth Sci., 5:993-1010. 
Emery, K. O., Uchupi, E., Phillips, J. D., Bowin, C. O., Bunce, E. T., and Knott, S. T., 1970. Continental Rise off Eastern North America. AAPG Bull., 54:44-108.

Floyd, P. A., Castillo, P. R., and Pringle, M., 1991. Tholeiitic and alkalic basalts of the oldest Pacific Ocean crust. Terra Nova, 3:257-265.

Furuta, T.. 1983. Magnetic properties of basalt samples from Holes 504B and 505B on the Costa Rica Rift, Deep Sea Drilling Project Legs 69 and 70. In Cann, J. R., Langseth, M. G., Honnorez, J., Von Herzen, R. P., White, S. M. et al., Init. Repts. DSDP, 69: Washington (U.S. Govt. Printing Office), $711-720$.

Furuta, T., and Levi, S., 1983. Basement paleomagnetism of Hole 504B. In Cann, J. R., Langseth, M. G., Honnorez, J., Von Herzen, R. P., White, S. M., et al. Init. Repts. DSDP, 69: Washington (U.S. Govt. Printing Office), 697-703.

Hall, J. M., and Robinson, P. T., 1979. Deep crustal drilling in the North Atlantic Ocean. Science, 204:573-586.

Handschumacher, D. W., Sager, W. W., Hilde, T.W.C., and Bracey, D. R., 1988. Pre-Cretaceous tectonic evolution of the Pacific plate and extension of the geomagnetic polarity reversal time scale with implications for the origin of the Jurassic "Quiet Zone." Tectonophysics, 155:365-380.

Harland, W. B., Cox, A. V., Llewellyn, P. G., Pickton, C.A.G., Smith, D. G., and Walters, R., 1982. A Geologic Time Scale: Cambridge (Cambridge Univ. Press).

Hayes, D. E., and Rabinowitz, P. D., 1975. Mesozoic magnetic lineations and the magnetic quiet zone off northwest Africa. Earth Planet. Sci. Lett., 28:105-115.

Heezen, B. C., MacGregor, I. D., et al., 1973. Init. Repts. DSDP, 20: Washington (U.S. Govt. Printing Office), 51-86.

Heirtzler, J. R., Dickson, G. O., Herron, E. M., Pitman, W. C., III, and LePichon, X., 1968. Marine magnetic anomalies, geomagnetic field reversals, and motions of the ocean floor and continents. J. Geophys. Res., 73:2119-2136.

Houtz, R., and Ewing, J., 1976. Upper crustal structure as a function of plate age. J. Geophys. Res., 81:2490-2498.

Irving, E., and Pullaiah, G., 1976. Reversals of the geomagnetic field, magnetostratigraphy, and relative magnitude of paleosecular variation in the Phanerozoic. Earth-Sci. Rev., 12:35-64.

Johnson, H. P., 1979. Paleomagnetism of igneous rock samples-DSDP Leg 45. In Melson, W. G., Rabinowitz, P. D., et al., Init. Repts. DSDP, 45 Washington (U.S. Govt. Printing Office), 397-406.

Kent, D. V., and Gradstein, F. M., 1985. A Cretaceous and Jurassic geochronology. Geol. Soc. Am. Bull., 96:1419-1427.

Kirschvink, J. L., 1980. The least-squares line and plane and the analysis of palaeomagnetic data. Geophys. J. R. Astron. Soc., 62:699-718.

Kono, M., 1980. Statistics of paleomagnetic inclination data. J. Geophys. Res., $85: 3878-3882$.

Lancelot, Y., Larson, R. L., et al., 1990. Proc. ODP, Init. Repts., 129: College Station, TX (Ocean Drilling Program).

Larson, R. L., 1976. Late Jurassic and Early Cretaceous evolution of the Western Central Pacific Ocean. J. Geomagn. Geoelectr., 28:219-236.

Larson, R. L., and Chase, C. G., 1972. Late Mesozoic evolution of the Western Pacific Ocean. Geol. Soc. Am. Bull., 83:3627-3644.

Larson, R. L., and Hilde, T.W.C., 1975, A revised time scale of magnetic reversals for the Early Cretaceous and Late Jurassic. J. Geophys. Res. $80: 2586-2594$.
Larson, R. L., and Pitman, W. C., III, 1972. World-wide correlation of Mesozoic magnetic anomalies, and its implications. Geol. Soc. Am. Bull., $83: 3645-3662$.

Lowrie, W., 1973. Viscous remanent magnetization in oceanic basalts. Nature, 243:27-30.

Ogg, J. G., Steiner, M. B., Wieczorek, J., and Hoffman, M., 1991. Jurassic magnetostratigraphy, 4. Early Callovian through middle Oxfordian of the Krakow Uplands (Poland), Earth Planet. Sci. Lett., 104:488-504.

Pitman, W. C., III, Herron, E. M., and Heirtzler, J. R., 1968. Magnetic anomalies in the Pacific and sea floor spreading. J. Geophys. Res., 73:2069-2085.

Poehls, K. A., Luyendyk, B. P., and Heirtzler, J. R., 1973. Magnetic smooth zones in the world's oceans. J. Geophys. Res., 78:6985-6997.

Shipboard Scientific Party, 1981. Site 462: Nauru Basin, western Pacific Ocean, Deep Sea Drilling Project Leg 61. In Larson, R. L., Schlanger, S. O., et al., Init. Repts. DSDP, 61: Washington (U.S. Govt. Printing Office), 19-394.

, 1983. Site 534: Blake-Bahama Basin. In Sheridan, R. E., Gradstein, F. M., et al., Init. Repts. DSDP, 76: Washington (U.S. Govt. Printing Office), 141-340.

, 1986a. Site 585. In Moberly, R., Schlanger, S. O., et al., Init. Repts. DSDP. 89: Washington (U.S. Govt. Printing Office), 29-155. 1986b. Site 462. In Moberly, R., Schlanger, S. O., et al., Init. Repts. DSDP, 89: Washington (U.S. Govt. Printing Office), 157-211. 1990. Site 801. In Lancelot, Y., Larson, R. L., et al., Proc. ODP, Init. Repts., 129: College Station, TX (Ocean Drilling Program), 91-170.

Shive, P. N., and Goodman, W. L., 1990. Induction coil magnetometer for rock magnetic studies (ABST). Eos, 71:1289.

Stacey, F. D., and Banerjee, S. K., 1974. The Physical Principles of Rock Magnetism: Amsterdam (Elsevier), Dev. in Solid Earth Geophysics Ser., 5.

Steiner, M. B., 1983. Paleomagnetism of middle Jurassic basalts, Deep Sea Drilling Project Leg 76. In Sheridan, R. E., Gradstein, F. M., et al., Init. Repts. DSDP, 76: Washington (U.S. Govt. Printing Office), 705-711.

Steiner, M. B., and Ogg, J. G., 1987. Oxfordian magnetic polarity patternreply to comment by R. E. Sheridan and K. A. Suydam. Earth Planet. Sci. Lett., 85:323-325.

Taylor, P. I., Zietz, I., and Dennis, L. S., 1968. Geological implications of aeromagnetic data for the eastern continental margin of the United States. Geophysics, 33:755-780.

Testarmata, M. M., and Gose, W. A., 1983. The susceptibility and time-dependent magnetization of basalts from Deep Sea Drilling Project Hole 534A, Blake Plateau. In Sheridan, R. E., Gradstein, F. M., et al., Init. Repts. DSDP, 76: Washington (U.S. Govt. Printing Office), 699-703.

Vogt, P. R., Anderson, C. N., and Bracey, D. R., 1971. Mesozoic magnetic anomalies, sea-floor spreading, and geomagnetic reversals in the southwestern Atlantic. J. Geophys. Res., 76:4796-4823.

Date of initial receipt: 17 June 1991

Date of acceptance: 13 March 1992

Ms 129B-135 

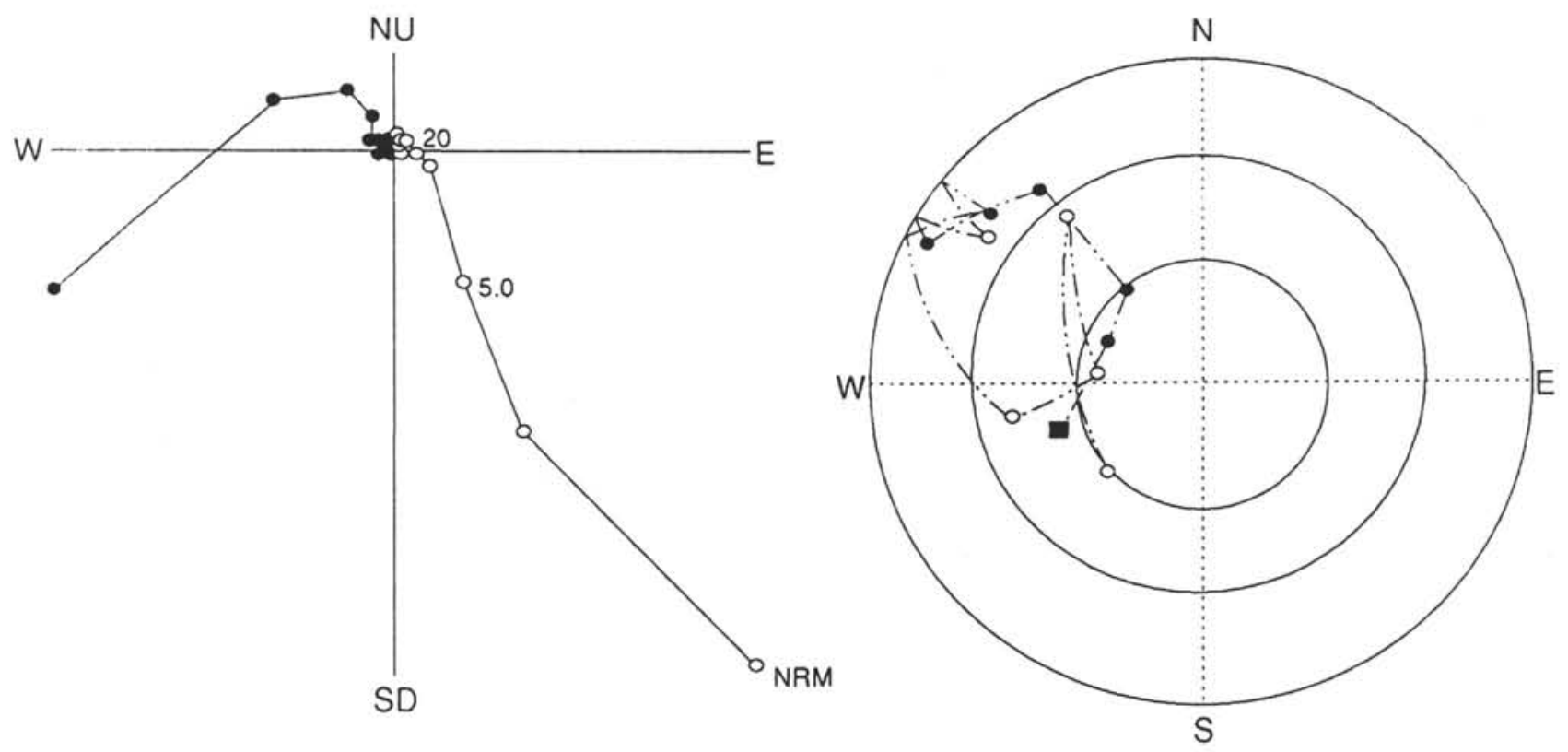

Figure 6. Vector projection diagram and stereographic projection of stepwise demagnetization of Sample $801 \mathrm{C}-6 \mathrm{R}-3,89 \mathrm{~cm}$, showing random vector displacements and numerous changes in sign. Conventions are the same as in Figure 4. 


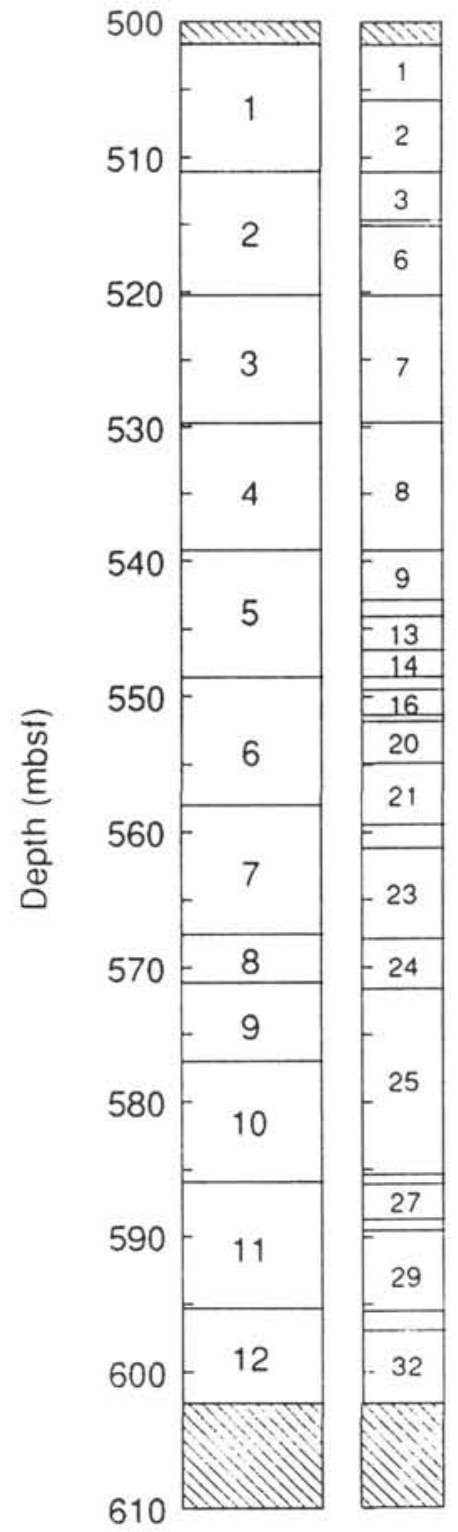

Core

Flow
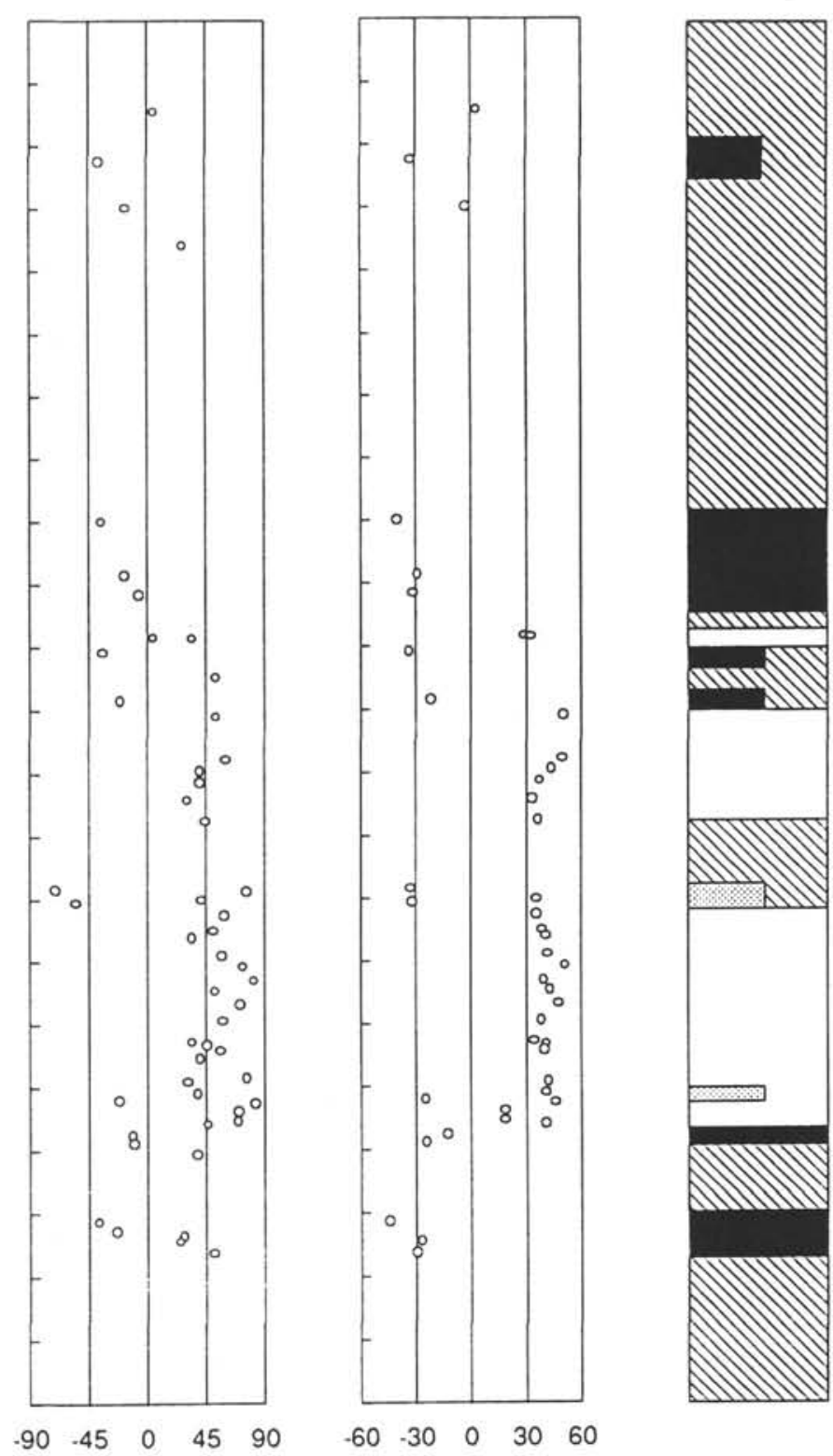

Polarity

Figure 7. Distribution with depth of NRM inclination, stable inclination, and polarity with depth. ODP core designations (far left column) and shipboard-defined igneous flow units (next column) are shown for comparison with the inclinations and polarity column. Note that the numbers of thin flow units have been omitted for brevity. The polarity column represents only those polarity events that can be defined with some certainty; the two apparently normal polarity samples corresponding to flow units 24 and 26 are part of a mixed polarity interval and therefore have uncertain affinities. These have been denoted by a stippled pattern while solid black and white bars represent normal and reversed polarity, respectively. Half bars indicate single samples at wide sampling intervals. 
Table 1. Complete results of paleomagnetic analysis of Hole $801 \mathrm{C}$ basalts tabulated by increasing depth.

\begin{tabular}{|c|c|c|c|c|c|c|c|c|c|c|c|c|c|c|}
\hline $\begin{array}{l}\text { Sample } \\
(\mathrm{cm})\end{array}$ & Flow & $\begin{array}{l}\text { Depth } \\
\text { (mbsf) }\end{array}$ & Pol. & $\begin{array}{l}\text { I NRM } \\
\left({ }^{\circ}\right)\end{array}$ & $\begin{array}{l}\mathrm{J}_{\mathrm{NRM}} \\
(\mathrm{A} / \mathrm{m}) \\
\end{array}$ & $\begin{array}{l}I_{\text {Isq }} \\
\left({ }^{\circ}\right)\end{array}$ & $\begin{array}{r}\mathrm{J}_{\mathrm{lsq}} \\
(\mathrm{A} / \mathrm{m})\end{array}$ & $\begin{array}{c}\chi \\
(\mathrm{SI}) \\
\end{array}$ & $\begin{array}{c}\begin{array}{c}\mathrm{H}_{\mathrm{s}} \\
(\mathrm{mT})\end{array} \\
\end{array}$ & $\begin{array}{c}\mathrm{J}_{\mathrm{s}} \\
(\mathrm{A} / \mathrm{m}) \\
\end{array}$ & $\begin{array}{c}\mathrm{J}_{\mathrm{Ts}} \\
(\mathrm{A} / \mathrm{m}) \\
\end{array}$ & $\begin{array}{c}\mathrm{H}_{\mathrm{c}} \\
(\mathrm{mT}) \\
\end{array}$ & $\begin{array}{l}\text { MDF } \\
(\mathrm{mT})\end{array}$ & Q \\
\hline $1 \mathrm{R}-4,106$ & 2 & 507.26 & $\mathbf{R}$ & 5.6 & 0.32 & 3.2 & 0.2391 & $1.79 \mathrm{E}-02$ & $\mathrm{n} / \mathrm{m}$ & $\mathrm{n} / \mathrm{m}$ & $\mathrm{n} / \mathrm{m}$ & $\mathrm{n} / \mathrm{m}$ & 29.9 & 0.50 \\
\hline $2 \mathrm{R}-1,19$ & 3 & 511.19 & NP & -36.6 & $3.22 \mathrm{E}-04$ & -32.3 & $2.71 \mathrm{E}-04$ & $5.30 \mathrm{E}-04$ & $\mathrm{n} / \mathrm{m}$ & $\mathrm{n} / \mathrm{m}$ & $\mathrm{n} / \mathrm{m}$ & $\mathrm{n} / \mathrm{m}$ & 40.3 & 0.02 \\
\hline $2 \mathrm{R}-3,95$ & 4 & 514.95 & NP & -16.0 & $4.93 \mathrm{E}-02$ & -2.3 & 0.0253 & $2.79 \mathrm{E}-03$ & $\mathrm{n} / \mathrm{m}$ & $\mathrm{n} / \mathrm{m}$ & $\mathrm{n} / \mathrm{m}$ & $\mathrm{n} / \mathrm{m}$ & 21.6 & 0.50 \\
\hline $2 R-5,96$ & 6 & 517.96 & $\mathrm{U}$ & 27.7 & 0.40 & & & $2.63 \mathrm{E}-02$ & $\mathrm{n} / \mathrm{m}$ & $\mathrm{n} / \mathrm{m}$ & $\mathrm{n} / \mathrm{m}$ & $\mathrm{n} / \mathrm{m}$ & 40.3 & 0.43 \\
\hline $5 \mathrm{R}-1,83$ & 9 & 540.03 & NP & -34.9 & $3.73 \mathrm{E}-04$ & -40.0 & $2.73 \mathrm{E}-04$ & $2.65 \mathrm{E}-04$ & $\mathrm{n} / \mathrm{m}$ & $\mathrm{n} / \mathrm{m}$ & $\mathrm{n} / \mathrm{m}$ & $\mathrm{n} / \mathrm{m}$ & 38.8 & 0.04 \\
\hline $5 R-4,56$ & 13 & 544.26 & $\mathrm{~N}$ & -17.2 & 0.47 & -28.9 & 0.1290 & $4.38 \mathrm{E}-03$ & $\mathrm{n} / \mathrm{m}$ & $\mathrm{n} / \mathrm{m}$ & $\mathrm{n} / \mathrm{m}$ & $\mathrm{n} / \mathrm{m}$ & 25.6 & 3.09 \\
\hline $5 R-5,59$ & 13 & 545.79 & $\mathrm{~N}$ & -6.1 & 0.43 & -31.5 & 0.1010 & $7.50 \mathrm{E}-03$ & $\mathrm{n} / \mathrm{m}$ & $\mathrm{n} / \mathrm{m}$ & $\mathrm{n} / \mathrm{m}$ & $\mathrm{n} / \mathrm{m}$ & 20.3 & 1.63 \\
\hline $6 \mathrm{R}-1,70$ & 15 & 549.20 & $\mathbf{R}$ & 4.7 & 0.16 & 28.7 & 0.0699 & $4.82 \mathrm{E}-03$ & $\mathrm{n} / \mathrm{m}$ & $\mathrm{n} / \mathrm{m}$ & $\mathrm{n} / \mathrm{m}$ & $\mathrm{n} / \mathrm{m}$ & 29.6 & 0.95 \\
\hline $6 \mathrm{R}-1,80$ & 15 & 549.30 & R & 34.8 & 0.21 & 32.4 & 0.0922 & 4.31E-03 & $\mathrm{n} / \mathrm{m}$ & $\mathrm{n} / \mathrm{m}$ & $\mathrm{n} / \mathrm{m}$ & $\mathrm{n} / \mathrm{m}$ & 26.7 & 1.39 \\
\hline $6 \mathrm{R}-2,40$ & 16 & 550.40 & $N$ & -34.3 & 1.05 & -33.3 & 0.7227 & 5.04E-03 & 99 & 500 & 200 & 21.1 & 23.1 & 5.96 \\
\hline $6 \mathrm{R}-3,89$ & 20 & 552.39 & U & 53.0 & 0.28 & & & 5.17E-03 & 80 & 475 & 184 & 11.7 & 2.5 & 1.53 \\
\hline $6 \mathrm{R}-4,123$ & 20 & 554.23 & $\mathrm{~N}$ & -20.6 & 0.97 & -21.5 & 0.4160 & $1.23 \mathrm{E}-02$ & 66 & 617 & 259 & 16.1 & 14.3 & 2.25 \\
\hline $6 \mathrm{R}-5,99$ & 21 & 555.49 & R & 52.9 & 6.83 & 49.9 & 1.1245 & $2.81 \mathrm{E}-02$ & 60 & 1834 & 709 & 10.6 & 9.6 & 6.92 \\
\hline $7 \mathrm{R}-1,83$ & 21 & 558.93 & R & 60.3 & 5.14 & 49.6 & 1.4500 & 1.92E-02 & 83 & 1688 & 688 & 14.4 & 18.4 & 7.64 \\
\hline 7R-2, 13 & 22 & 559.73 & R & 40.9 & 2.94 & 43.8 & 1.2400 & $2.65 \mathrm{E}-02$ & 67 & 1771 & 667 & 13.3 & 16.6 & 3.16 \\
\hline $7 R-2,109$ & 22 & 560.69 & R & 40.2 & 11.27 & 37.3 & 2.0791 & $2.76 \mathrm{E}-02$ & 68 & 1896 & 813 & 13.9 & 12.1 & 11.65 \\
\hline $7 R-3,96$ & 23 & 562.06 & R & 30.9 & 6.39 & 33.4 & 0.3610 & $5.56 \mathrm{E}-02$ & 36 & 2500 & 666 & 4.5 & 23.6 & 3.28 \\
\hline $7 R-4,114$ & 23 & 563.74 & R & 44.6 & 5.46 & 36.6 & 0.6390 & $3.85 \mathrm{E}-02$ & 38 & 2292 & 791 & 5.0 & 5.0 & 4.04 \\
\hline $8 \mathrm{R}-2,18$ & 24 & 569.18 & NP & -70.5 & 0.26 & -32.8 & 0.0534 & $1.89 \mathrm{E}-02$ & 79 & 1563 & 542 & 13.9 & 15.7 & 0.39 \\
\hline $8 \mathrm{R}-2,31$ & 24 & 569.31 & U & 75.9 & 1.84 & & & 3.17E-02 & 61 & 2708 & 958 & 6.7 & 3.2 & 1.65 \\
\hline $8 R-2,103$ & 24 & 570.03 & R & 41.5 & 2.34 & 35.5 & 1.0173 & 2.04E-02 & 73 & 1896 & 792 & 16.7 & 16.6 & 3.26 \\
\hline $8 R-2,127$ & 24 & 570.27 & $\mathrm{~N}$ & -54.9 & 3.34 & -32.0 & 0.2040 & $2.92 \mathrm{E}-02$ & 72 & 2791 & 958 & 8.8 & 8.4 & 3.26 \\
\hline $9 \mathrm{R}-1,3$ & 25 & 571.23 & $R$ & 59.1 & 4.36 & 35.4 & 0.4320 & $4.16 \mathrm{E}-02$ & 58 & 2958 & 916 & 5.0 & 7.5 & 2.99 \\
\hline $9 \mathrm{R}-1,130$ & 25 & 572.50 & $\mathrm{R}$ & 50.4 & 9.36 & 38.4 & 0.4882 & $2.60 \mathrm{E}-02$ & 44 & 1792 & 709 & 7.3 & 4.9 & 10.27 \\
\hline $9 \mathrm{R}-2,31$ & 25 & 573.01 & R & 34.5 & 3.47 & 40.4 & 0.2050 & $3.18 \mathrm{E}-02$ & 43 & 1604 & 542 & 6.2 & 4.2 & 3.11 \\
\hline $9 R-3,26$ & 25 & 574.46 & R & 57.5 & 3.91 & 41.2 & 0.3720 & $3.81 \mathrm{E}-02$ & 36 & 1855 & 521 & 3.9 & 4.4 & 2.93 \\
\hline $9 \mathrm{R}-3,117$ & 25 & 575.37 & $\mathrm{R}$ & 73.2 & 3.07 & 50.9 & 0.1450 & 4.16E-02 & 39 & 1771 & 438 & 5.0 & 5.1 & 2.10 \\
\hline $9 \mathrm{R}-4,79$ & 25 & 576.49 & $\mathrm{R}$ & 81.7 & 4.03 & 39.5 & 0.3529 & $3.74 \mathrm{E}-02$ & 33 & 1646 & 480 & 3.6 & 4.0 & 3.07 \\
\hline $10 \mathrm{R}-1,33$ & 25 & 577.33 & R & 52.1 & 4.04 & 42.9 & 0.4971 & $3.74 \mathrm{E}-02$ & 31 & 1855 & 583 & 3.9 & 3.4 & 3.08 \\
\hline 10R-1-139 & 25 & 578.39 & $\mathrm{R}$ & 71.2 & 5.06 & 47.4 & 0.2540 & 4.03E-02 & 33 & 1625 & 459 & 3.4 & 2.9 & 3.58 \\
\hline $10 \mathrm{R}-2,120$ & 25 & 579.70 & $\mathrm{R}$ & 57.7 & 1.96 & 38.1 & 0.4990 & $3.47 \mathrm{E}-02$ & 34 & 1729 & 521 & 4.2 & 12.8 & 1.61 \\
\hline IOR-3, 137 & 25 & 581.37 & R & 34.6 & 10.82 & 34.0 & 0.9910 & 2.65E-02 & 38 & 2188 & 417 & 6.2 & 5.2 & 11.63 \\
\hline $10 R-4,11$ & 25 & 581.61 & $\mathbf{R}$ & 45.7 & 8.83 & 40.7 & 1.1800 & $2.70 \mathrm{E}-02$ & 37 & 1583 & 646 & 5.6 & 6.4 & 9.34 \\
\hline $10 \mathrm{R}-4,58$ & 25 & 582.08 & $\mathbf{R}$ & 56.0 & 3.39 & 39.7 & 0.7735 & $3.16 \mathrm{E}-02$ & 31 & 1563 & 438 & 3.4 & 5.8 & 3.06 \\
\hline $10 \mathrm{R}-4,114$ & 25 & 582.65 & $\mathrm{U}$ & 40.7 & 0.89 & & & 4.07E-02 & 30 & 1646 & 396 & 2.5 & 4.2 & 0.62 \\
\hline $10 \mathrm{R}-5,122$ & 25 & 584.22 & $\mathrm{U}$ & 76.5 & 1.63 & & & 4.15E-02 & 28 & 1521 & 396 & 2.8 & 2.4 & 1.12 \\
\hline $10 \mathrm{R}-6,7$ & 25 & 584.57 & RP & 31.2 & 1.76 & 42.2 & 0.1140 & 4.24E-02 & 31 & 2499 & 1583 & 2.5 & 4.5 & 1.18 \\
\hline 10R-6, 95 & 26 & 585.45 & RP & 38.7 & 2.96 & 40.4 & 0.0831 & $1.75 \mathrm{E}-02$ & 40 & 1073 & 312 & 6.2 & 4.5 & 4.83 \\
\hline $11 \mathrm{R}-1,9$ & 26 & 585.99 & NP & -21.3 & 2.35 & -24.5 & 0.0329 & $5.15 \mathrm{E}-02$ & 57 & 3916 & 1250 & 7.8 & 6.7 & 1.30 \\
\hline $11 \mathrm{R}-1,36$ & 27 & 586.26 & RP & 82.8 & 1.26 & 45.7 & 0.0752 & $5.81 \mathrm{E}-02$ & 37 & 3542 & 1042 & 5.3 & 4.3 & 0.62 \\
\hline $11 \mathrm{R}-1,100$ & 27 & 586.90 & RP & 69.8 & 1.55 & 18.5 & 0.1180 & $5.48 \mathrm{E}-02$ & 58 & 4333 & 1417 & 6.1 & 3.7 & 0.81 \\
\hline $11 \mathrm{R}-2,22$ & 27 & 587.62 & RP & 69.7 & 2.99 & 18.5 & 0.0529 & $3.96 \mathrm{E}-02$ & 57 & 3417 & 1375 & 8.9 & 4.1 & 2.15 \\
\hline $11 \mathrm{R}-2,48$ & 27 & 587.88 & $\mathbf{R}$ & 46.8 & 6.54 & 40.5 & 0.5140 & 4.44E-02 & 41 & 3125 & 1042 & 6.4 & 6.3 & 4.20 \\
\hline $11 \mathrm{R}-2,139$ & 28 & 588.79 & $\mathrm{~N}$ & -10.8 & 13.27 & -12.9 & 2.0018 & $2.45 \mathrm{E}-02$ & 58 & 3499 & 1167 & 12.8 & 9.4 & 15.42 \\
\hline $11 R-3,52$ & 28 & 589.42 & $\mathrm{~N}$ & -9.9 & 1.75 & -24.0 & 0.3022 & 2.19E-02 & 46 & 1479 & 417 & 7.6 & 12.7 & 2.28 \\
\hline $11 \mathrm{R}-3,140$ & 29 & 590.30 & U & 38.3 & 0.39 & & & 2.83E-02 & 44 & 1834 & 625 & 8.4 & 7.2 & 0.39 \\
\hline $12 \mathrm{R}-1,037$ & 30 & 595.67 & $\mathrm{~N}$ & -36.8 & 0.62 & -44.4 & 0.1491 & 4.05E-02 & 46 & 2625 & 791 & 8.7 & 9.0 & 0.44 \\
\hline I2R-1, 107 & 31 & 596.37 & U & -23.3 & 0.65 & & & $5.08 \mathrm{E}-02$ & 42 & 3292 & 1028 & 8.1 & 6.8 & 0.37 \\
\hline $12 \mathrm{R}-1,144$ & 31 & 596.74 & $\mathrm{U}$ & 28.6 & 0.57 & & & $5.24 \mathrm{E}-02$ & 43 & 3085 & 1085 & 7.8 & 4.4 & 0.31 \\
\hline $12 \mathrm{R}-2,42$ & 32 & 597.22 & NP & 25.7 & 0.60 & -26.6 & 0.0355 & $5.09 \mathrm{E}-02$ & 32 & 1250 & 570 & 4.0 & 1.9 & 0.34 \\
\hline $12 \mathrm{R}-2,134$ & 32 & 598.14 & $\mathrm{~N}$ & 51.5 & 3.51 & -29.4 & 0.5988 & $3.61 \mathrm{E}-02$ & 8 & 3750 & 1315 & 6.0 & 2.3 & 2.77 \\
\hline
\end{tabular}

Notes: "Flow unit" refers to the numbered flow unit as labeled by shipboard igneous petrologists (Shipboard Scientific Party, 1990). Polarity designations reflect varying degrees of certainty in determination. See additional details in text. Blanks indicate there were no applicable measurements; "n.m." indicates that no measurements were made for that sample. 
APPENDIX

\begin{tabular}{|c|c|c|c|c|}
\hline $\begin{array}{l}\text { Sample } \\
(\mathrm{cm})\end{array}$ & $\begin{array}{l}\text { AF level } \\
(\mathrm{mT})\end{array}$ & $\begin{array}{l}\text { Declination } \\
\text { (degrees) }\end{array}$ & $\begin{array}{l}\text { Inclination } \\
\text { (degrees) }\end{array}$ & $\begin{array}{l}\text { Intensity } \\
(\mathrm{A} / \mathrm{m})\end{array}$ \\
\hline \multirow[t]{10}{*}{$801 C-1 R-4,106$} & 0.0 & 170.8 & 5.6 & 0.3160 \\
\hline & 2.5 & 164.0 & 9.0 & 0.4860 \\
\hline & 5.0 & 163.7 & 7.1 & 0.5670 \\
\hline & 10.0 & 163.0 & 3.1 & 0.4700 \\
\hline & 15.0 & 162.8 & 2.6 & 0.3490 \\
\hline & 20.0 & 162.9 & 2.2 & 0.2730 \\
\hline & 30.0 & 162.1 & 2.6 & 0.1570 \\
\hline & 40.0 & 161.8 & 1.7 & 0.0744 \\
\hline & 50.0 & 159.6 & 1.7 & 0.0315 \\
\hline & 60.0 & 164.3 & 3.4 & 0.0319 \\
\hline \multirow[t]{9}{*}{$801 C-2 R-1,19$} & 0.0 & 273.2 & -36.6 & $3.22 \mathrm{E}-04$ \\
\hline & 2.5 & 271.7 & -37.8 & $3.23 \mathrm{E}-04$ \\
\hline & 5.0 & 268.2 & -34.1 & $3.24 \mathrm{E}-04$ \\
\hline & 10.0 & 267.9 & -30.9 & $2.92 \mathrm{E}-04$ \\
\hline & 15.0 & 266.1 & -31.6 & 2.83E-04 \\
\hline & 20.0 & 261.8 & -31.0 & $2.56 \mathrm{E}-04$ \\
\hline & 30.0 & 251.3 & -30.7 & $1.98 \mathrm{E}-04$ \\
\hline & 40.0 & 247.1 & -20.8 & 1.62E-04 \\
\hline & 50.0 & 234.5 & -10.1 & $1.30 \mathrm{E}-04$ \\
\hline \multirow[t]{9}{*}{$801 C-2 R-3,95$} & 0.0 & 242.8 & -16.0 & 0.0493 \\
\hline & 2.5 & 261.5 & -18.2 & 0.0522 \\
\hline & 5.0 & 267.0 & -14.8 & 0.0527 \\
\hline & 10.0 & 262.3 & -7.3 & 0.0490 \\
\hline & 15.0 & 257.9 & -1.1 & 0.0369 \\
\hline & 20.0 & 256.9 & -0.8 & 0.0270 \\
\hline & 30.0 & 252.4 & 1.4 & 0.0121 \\
\hline & 40.0 & 234.0 & 6.7 & 0.0054 \\
\hline & 50.0 & 216.6 & 16.9 & 0.0031 \\
\hline \multirow{9}{*}{$801 C-2 R-5,96$} & 0.0 & 308.5 & 27.7 & 0.3964 \\
\hline & 2.5 & 311.2 & 15.4 & 0.2627 \\
\hline & 5.0 & 284.1 & 4.8 & 0.1109 \\
\hline & 10.0 & 253.1 & -6.4 & 0.0343 \\
\hline & 15.0 & 244.3 & 3.3 & 0.0125 \\
\hline & 20.0 & 233.8 & 12.0 & 0.0042 \\
\hline & 25.0 & 210.3 & 17.6 & 0.0059 \\
\hline & 30.0 & 217.5 & 21.5 & 0.0048 \\
\hline & 35.0 & 203.3 & 3.6 & 0.0030 \\
\hline \multirow[t]{9}{*}{$801 C-5 R-1,83$} & 0.0 & 137.5 & -34.9 & $3.73 \mathrm{E}-04$ \\
\hline & 2.5 & 136.3 & -32.9 & $3.81 \mathrm{E}-04$ \\
\hline & 5.0 & 136.2 & -33.0 & $3.79 \mathrm{E}-04$ \\
\hline & 10.0 & 134.8 & -32.3 & $3.51 \mathrm{E}-04$ \\
\hline & 15.0 & 132.2 & -32.3 & $3.22 \mathrm{E}-04$ \\
\hline & 20.0 & 134.5 & -30.4 & 2.77E-04 \\
\hline & 30.0 & 134.5 & -28.5 & $2.19 \mathrm{E}-04$ \\
\hline & 40.0 & 133.7 & -29.5 & $1.82 \mathrm{E}-04$ \\
\hline & 50.0 & 131.2 & -26.8 & 1.67E-04 \\
\hline \multirow[t]{14}{*}{$801 C-5 R-4,56$} & 0.0 & 42.8 & -17.2 & 0.4740 \\
\hline & 2.5 & 43.6 & -14.2 & 0.4482 \\
\hline & 5.0 & 132.4 & -18.5 & 0.4809 \\
\hline & 10.0 & 43.2 & -23.2 & 0.4473 \\
\hline & 15.0 & 44.9 & -26.6 & 0.3809 \\
\hline & 20.0 & 45.9 & -26.3 & 0.3100 \\
\hline & 25.0 & 45.7 & -26.2 & 0.2445 \\
\hline & 30.0 & 46.7 & -27.3 & 0.1855 \\
\hline & 35.0 & 45.7 & -26.4 & 0.1436 \\
\hline & 40.0 & 46.4 & -25.9 & 0.1073 \\
\hline & 45.0 & 47.7 & -25.1 & 0.0799 \\
\hline & 50.0 & 44.4 & -23.6 & 0.0569 \\
\hline & 55.0 & 42.5 & -21.1 & 0.0415 \\
\hline & 60.0 & 44.7 & -20.1 & 0.0331 \\
\hline \multirow[t]{11}{*}{$801 C-5 R-5,59$} & 0.0 & 217.7 & -6.1 & 0.4255 \\
\hline & 2.5 & 217.8 & -10.3 & 0.4645 \\
\hline & 5.0 & 219.0 & -15.4 & 0.4664 \\
\hline & 10.0 & 219.3 & -25.1 & 0.3673 \\
\hline & 15.0 & 220.8 & -30.4 & 0.2791 \\
\hline & 20.0 & 222.0 & -32.0 & 0.2155 \\
\hline & 25.0 & 222.3 & -32.7 & 0.1682 \\
\hline & 30.0 & 223.5 & -32.3 & 0.1318 \\
\hline & 35.0 & 224.3 & -34.0 & 0.1082 \\
\hline & 40.0 & 224.0 & -34.5 & 0.0855 \\
\hline & 45.0 & 227.9 & -35.2 & 0.0686 \\
\hline
\end{tabular}

APPENDIX (continued).

\begin{tabular}{|c|c|c|c|c|}
\hline $\begin{array}{l}\text { Sample } \\
(\mathrm{cm})\end{array}$ & $\begin{array}{c}\text { AF level } \\
(\mathrm{mT})\end{array}$ & $\begin{array}{c}\text { Declination } \\
\text { (degrees) }\end{array}$ & $\begin{array}{l}\text { Inclination } \\
\text { (degrees) }\end{array}$ & $\begin{array}{c}\text { Intensity } \\
(\mathrm{A} / \mathrm{m})\end{array}$ \\
\hline & 50.0 & 225.5 & -33.4 & 0.0551 \\
\hline & 55.0 & 223.7 & -32.9 & 0.0405 \\
\hline & 60.0 & 226.7 & -35.7 & 0.0358 \\
\hline \multirow[t]{14}{*}{$801 \mathrm{C}-6 \mathrm{R}-1,70$} & 0.0 & 256.6 & 4.7 & 0.1564 \\
\hline & 2.5 & 252.3 & 9.6 & 0.1555 \\
\hline & 5.0 & 254.7 & 15.4 & 0.1636 \\
\hline & 10.0 & 250.0 & 23.7 & 0.1482 \\
\hline & 15.0 & 248.7 & 26.6 & 0.1364 \\
\hline & 20.0 & 249.0 & 28.5 & 0.1173 \\
\hline & 25.0 & 246.9 & 29.7 & 0.0964 \\
\hline & 30.0 & 246.3 & 29.9 & 0.0765 \\
\hline & 35.0 & 244.1 & 29.4 & 0.0593 \\
\hline & 40.0 & 242.7 & 30.0 & 0.0431 \\
\hline & 45.0 & 243.0 & 28.6 & 0.0267 \\
\hline & 50.0 & 235.7 & 16.4 & 0.0146 \\
\hline & 55.0 & 222.3 & -34.6 & 0.0095 \\
\hline & 60.0 & 214.2 & -47.4 & 0.0067 \\
\hline \multirow[t]{14}{*}{$801 C-6 R-1,80$} & 0.0 & 250.1 & 34.8 & 0.2091 \\
\hline & 2.5 & 249.7 & 25.1 & 0.1900 \\
\hline & 5.0 & 250.1 & 25.7 & 0.1791 \\
\hline & 10.0 & 244.4 & 28.5 & 0.1682 \\
\hline & 15.0 & 237.5 & 37.6 & 0.1509 \\
\hline & 20.0 & 241.0 & 31.7 & 0.1300 \\
\hline & 25.0 & 240.6 & 31.9 & 0.1118 \\
\hline & 30.0 & 239.4 & 32.6 & 0.0909 \\
\hline & 35.0 & 240.1 & 32.4 & 0.0733 \\
\hline & 40.0 & 239.8 & 30.1 & 0.0547 \\
\hline & 45.0 & 235.4 & 28.4 & 0.0415 \\
\hline & 50.0 & 233.8 & 25.3 & 0.0273 \\
\hline & 55.0 & 230.4 & 11.5 & 0.0155 \\
\hline & 60.0 & 238.8 & 10.0 & 0.0090 \\
\hline \multirow[t]{11}{*}{$801 \mathrm{C}-6 \mathrm{R}-2,40$} & 0.0 & 216.6 & -34.3 & 1.0545 \\
\hline & 2.5 & 215.9 & -32.9 & 1.0364 \\
\hline & 5.0 & 216.2 & -32.9 & 1.0182 \\
\hline & 10.0 & 214.4 & -34.3 & 0.9273 \\
\hline & 20.0 & 214.8 & -33.8 & 0.6145 \\
\hline & 30.0 & 215.4 & -33.5 & 0.3309 \\
\hline & 40.0 & 213.7 & -28.5 & 0.1545 \\
\hline & 45.0 & 213.9 & -21.8 & 0.1009 \\
\hline & 50.0 & 212.8 & -11.6 & 0.0699 \\
\hline & 55.0 & 210.8 & 3.1 & 0.0528 \\
\hline & 60.0 & 207.1 & 16.7 & 0.0464 \\
\hline \multirow[t]{11}{*}{$801 \mathrm{C}-6 \mathrm{R}-3,89$} & 0.0 & 249.4 & 53.0 & 0.2773 \\
\hline & 2.5 & 291.6 & 64.2 & 0.1364 \\
\hline & 5.0 & 319.3 & 61.4 & 0.0674 \\
\hline & 10.0 & 323.0 & 22.8 & 0.0199 \\
\hline & 15.0 & 292.7 & 10.7 & 0.0110 \\
\hline & 20.0 & 300.3 & -26.6 & 0.0090 \\
\hline & 30.0 & 307.4 & 20.0 & 0.0044 \\
\hline & 40.0 & 258.4 & -41.2 & 0.0087 \\
\hline & 45.0 & 274.1 & -64.5 & 0.0069 \\
\hline & 50.0 & 323.0 & -34.4 & 0.0050 \\
\hline & 55.0 & 223.7 & -59.5 & 0.0052 \\
\hline \multirow[t]{14}{*}{$801 \mathrm{C}-6 \mathrm{R}-4,123$} & 0.0 & 333.7 & -20.6 & 0.9727 \\
\hline & 2.5 & 333.1 & -20.6 & 0.9545 \\
\hline & 5.0 & 331.3 & -21.5 & 0.9091 \\
\hline & 10.0 & 330.4 & -21.6 & 0.7127 \\
\hline & 15.0 & 329.8 & -22.0 & 0.4491 \\
\hline & 20.0 & 330.5 & -22.4 & 0.2482 \\
\hline & 25.0 & 335.3 & -21.4 & 0.1209 \\
\hline & 30.0 & 350.8 & -19.6 & 0.0537 \\
\hline & 35.0 & 30.0 & -6.6 & 0.0262 \\
\hline & 40.0 & 66.2 & 7.1 & 0.0279 \\
\hline & 45.0 & 78.4 & 17.4 & 0.0355 \\
\hline & 50.0 & 81.8 & 18.5 & 0.0404 \\
\hline & 55.0 & 85.1 & 9.3 & 0.0360 \\
\hline & 60.0 & 85.1 & 21.2 & 0.0438 \\
\hline \multirow[t]{4}{*}{$801 C-6 R-5,99$} & 0.0 & 21.7 & 52.9 & 6.8273 \\
\hline & 2.5 & 22.9 & 52.2 & 6.5545 \\
\hline & 5.0 & 22.7 & 52.4 & 5.7818 \\
\hline & 10.0 & 22.9 & 49.9 & 3.2273 \\
\hline
\end{tabular}


APPENDIX (continued).

\begin{tabular}{|c|c|c|c|c|}
\hline $\begin{array}{c}\text { Sample } \\
\text { (cm) }\end{array}$ & $\begin{array}{l}\text { AF level } \\
(\mathrm{mT})\end{array}$ & $\begin{array}{c}\text { Declination } \\
\text { (degrees) }\end{array}$ & $\begin{array}{l}\text { Inclination } \\
\text { (degrees) }\end{array}$ & $\begin{array}{c}\text { Intensity } \\
(\mathrm{A} / \mathrm{m})\end{array}$ \\
\hline & 15.0 & 22.6 & 49.2 & 1.7273 \\
\hline & 20.0 & 22.0 & 49.1 & 1.0545 \\
\hline & 25.0 & 21.2 & 48.9 & 0.6973 \\
\hline & 30.0 & 20.2 & 49.3 & 0.4991 \\
\hline & 35.0 & 18.0 & 49.1 & 0.3755 \\
\hline & 40.0 & 17.3 & 51.0 & 0.2936 \\
\hline & 45.0 & 14.9 & 50.3 & 0.2345 \\
\hline & 50.0 & 12.6 & 50.1 & 0.1936 \\
\hline & 55.0 & 7.2 & 51.3 & 0.1591 \\
\hline & 60.0 & 3.1 & 50.6 & 0.1400 \\
\hline \multirow[t]{14}{*}{$801 \mathrm{C}-7 \mathrm{R}-1,83$} & 0.0 & 101.8 & 60.3 & 5.1455 \\
\hline & 2.5 & 101.5 & 55.5 & 4.8182 \\
\hline & 5.0 & 101.0 & 53.2 & 4.6000 \\
\hline & 10.0 & 102.7 & 50.5 & 3.9636 \\
\hline & 15.0 & 105.7 & 49.9 & 3.0909 \\
\hline & 20.0 & 104.1 & 49.4 & 2.3364 \\
\hline & 25.0 & 104.3 & 49.1 & 1.7091 \\
\hline & 30.0 & 104.7 & 49.0 & 1.2273 \\
\hline & 35.0 & 105.2 & 49.0 & 0.8518 \\
\hline & 40.0 & 104.9 & 50.2 & 0.5745 \\
\hline & 45.0 & 105.1 & 51.8 & 0.3809 \\
\hline & 50.0 & 103.8 & 53.4 & 0.2536 \\
\hline & 55.0 & 103.2 & 58.6 & 0.1755 \\
\hline & 60.0 & 104.5 & 62.8 & 0.1364 \\
\hline \multirow[t]{12}{*}{$801 C-7 R-2,13$} & 0.0 & 351.5 & 40.9 & 2.9455 \\
\hline & 2.5 & 351.4 & 42.4 & 2.9636 \\
\hline & 5.0 & 351.2 & 42.2 & 2.8818 \\
\hline & 10.0 & 351.3 & 42.9 & 2.3364 \\
\hline & 15.0 & 351.1 & 42.7 & 1.6455 \\
\hline & 20.0 & 350.4 & 42.2 & 1.0909 \\
\hline & 25.0 & 350.3 & 41.0 & 0.6991 \\
\hline & 30.0 & 349.5 & 38.6 & 0.4309 \\
\hline & 35.0 & 347.4 & 32.6 & 0.2591 \\
\hline & 40.0 & 344.2 & 22.0 & 0.1527 \\
\hline & 45.0 & 340.5 & 3.4 & 0.1018 \\
\hline & 50.0 & 339.0 & -21.4 & 0.0783 \\
\hline \multirow[t]{10}{*}{$801 C-7 R-2,109$} & 0.0 & 1.0 & 40.2 & 11.2727 \\
\hline & 2.5 & 1.5 & 38.4 & 11.3636 \\
\hline & 5.0 & 1.6 & 38.4 & 10.5455 \\
\hline & 10.0 & 1.8 & 37.2 & 6.5818 \\
\hline & 20.0 & 1.7 & 37.4 & 2.1182 \\
\hline & 30.0 & 0.9 & 36.4 & 0.8227 \\
\hline & 35.0 & 359.6 & 36.7 & 0.5209 \\
\hline & 40.0 & 359.2 & 36.5 & 0.3527 \\
\hline & 50.0 & 352.4 & 32.2 & 0.1845 \\
\hline & 60.0 & 343.3 & 29.7 & 0.0991 \\
\hline \multirow[t]{11}{*}{$801 C-7 R-3,96$} & 0.0 & 291.3 & 30.9 & 6.3909 \\
\hline & 2.5 & 274.5 & 33.2 & 3.0091 \\
\hline & 5.0 & 273.9 & 33.1 & 1.9727 \\
\hline & 10.0 & 273.6 & 33.3 & 1.0636 \\
\hline & 15.0 & 272.9 & 33.9 & 0.6100 \\
\hline & 20.0 & 270.7 & 33.8 & 0.3700 \\
\hline & 25.0 & 268.3 & 33.0 & 0.2218 \\
\hline & 30.0 & 271.0 & 33.4 & 0.1318 \\
\hline & 35.0 & 271.4 & 36.3 & 0.0817 \\
\hline & 40.0 & 266.5 & 29.7 & 0.0479 \\
\hline & 45.0 & 251.2 & 37.1 & 0.0250 \\
\hline \multirow[t]{14}{*}{$801 C-7 R-4,114$} & 0.0 & 349.4 & 44.6 & 5.4636 \\
\hline & 2.5 & 340.7 & 38.2 & 4.2818 \\
\hline & 5.0 & 337.7 & 36.4 & 2.7364 \\
\hline & 10.0 & 336.2 & 36.7 & 1.4545 \\
\hline & 15.0 & 334.5 & 36.8 & 1.0636 \\
\hline & 20.0 & 335.2 & 37.6 & 0.8709 \\
\hline & 25.0 & 335.1 & 37.3 & 0.7182 \\
\hline & 30.0 & 334.3 & 37,4 & 0.5900 \\
\hline & 35.0 & 334.6 & 37.2 & 0.4882 \\
\hline & 40.0 & 333.5 & 37.7 & 0.3964 \\
\hline & 45.0 & 336.8 & 37.9 & 0.3327 \\
\hline & 50.0 & 336.0 & 37.9 & 0.2618 \\
\hline & 55.0 & 334.7 & 36.9 & 0.2127 \\
\hline & 60.0 & 339.6 & 41.7 & 0.1736 \\
\hline
\end{tabular}

APPENDIX (continued).

\begin{tabular}{|c|c|c|c|c|}
\hline $\begin{array}{l}\text { Sample } \\
(\mathrm{cm})\end{array}$ & $\begin{array}{c}\text { AF level } \\
(\mathrm{mT})\end{array}$ & $\begin{array}{l}\text { Declination } \\
\text { (degrees) }\end{array}$ & $\begin{array}{l}\text { Inclination } \\
\text { (degrees) }\end{array}$ & $\begin{array}{c}\text { Intensity } \\
(\mathrm{A} / \mathrm{m})\end{array}$ \\
\hline \multirow[t]{14}{*}{$801 \mathrm{C}-8 \mathrm{R}-2,18$} & 0.0 & 114.6 & -70.5 & 0.2582 \\
\hline & 2.5 & 110.9 & -68.1 & 0.2727 \\
\hline & 5.0 & 86.2 & -60.0 & 0.2600 \\
\hline & 10.0 & 84.6 & -49.9 & 0.2018 \\
\hline & 15.0 & 76.6 & -40.5 & 0.1373 \\
\hline & 20.0 & 70.9 & -32.9 & 0.0821 \\
\hline & 25.0 & 67.0 & -31.7 & 0.0471 \\
\hline & 30.0 & 68.7 & -33.6 & 0.0309 \\
\hline & 35.0 & 65.8 & -45.6 & 0.0227 \\
\hline & 40.0 & 65.9 & -50.8 & 0.0220 \\
\hline & 45.0 & 70.0 & 58.0 & 0.0155 \\
\hline & 50.0 & 77.7 & -55.9 & 0.0224 \\
\hline & 55.0 & 71.2 & -63.4 & 0.0244 \\
\hline & 60.0 & 76.2 & -55.5 & 0.0237 \\
\hline \multirow[t]{12}{*}{$801 \mathrm{C}-8 \mathrm{R}-2,31$} & 0.0 & 262.8 & 3.5 & 1.8455 \\
\hline & 2.5 & 114.0 & 79.3 & 1.0727 \\
\hline & 5.0 & 147.1 & 76.5 & 0.5473 \\
\hline & 10.0 & 161.1 & 62.7 & 0.2009 \\
\hline & 15.0 & 188.5 & 71.7 & 0.0991 \\
\hline & 20.0 & 251.7 & 74.8 & 0.0515 \\
\hline & 25.0 & 298.2 & 74.5 & 0.0193 \\
\hline & 30.0 & 311.0 & 64.7 & 0.0453 \\
\hline & 35.0 & 352.3 & 39.5 & 0.0261 \\
\hline & 40.0 & 359.9 & 29.6 & 0.0292 \\
\hline & 45.0 & 353.9 & 17.9 & 0.0260 \\
\hline & 50.0 & 341.4 & 25.1 & 0.0243 \\
\hline \multirow[t]{14}{*}{$801 C-8 R-2,103$} & 0.0 & 196.0 & 41.5 & 2.3364 \\
\hline & 2.5 & 195.4 & 40.5 & 2.3818 \\
\hline & 5.0 & 185.2 & 43.3 & 2.1727 \\
\hline & 10.0 & 193.7 & 33.8 & 1.8727 \\
\hline & 15.0 & 192.7 & 32.0 & 1.2818 \\
\hline & 20.0 & 194.5 & 30.7 & 0.9273 \\
\hline & 25.0 & 193.1 & 29.8 & 0.5945 \\
\hline & 30.0 & 193.6 & 27.4 & 0.4109 \\
\hline & 35.0 & 193.8 & 23.3 & 0.2800 \\
\hline & 40.0 & 195.2 & 17.0 & 0.2018 \\
\hline & 45.0 & 197.8 & 6.4 & 0.1527 \\
\hline & 50.0 & 202.4 & -6.6 & 0.1245 \\
\hline & 55.0 & 204.5 & -22.1 & 0.1064 \\
\hline & 60.0 & 208.9 & -36.6 & 0.1036 \\
\hline \multirow[t]{14}{*}{$801 C-8 R-2,127$} & 0.0 & 151.9 & -54.9 & 3.3364 \\
\hline & 2.5 & 149.4 & -46.3 & 3.0364 \\
\hline & 5.0 & 149.3 & -39.5 & 2.4818 \\
\hline & 10.0 & 148.2 & -33.2 & 1.2727 \\
\hline & 15.0 & 148.5 & -31.4 & 0.6509 \\
\hline & 20.0 & 148.9 & -31.7 & 0.3755 \\
\hline & 25.0 & 146.8 & -29.8 & 0.2564 \\
\hline & 30.0 & 147.9 & -28.4 & 0.1773 \\
\hline & 35.0 & 149.0 & -28.6 & 0.1518 \\
\hline & 40.0 & 147.1 & -28.1 & 0.1218 \\
\hline & 45.0 & 142.5 & -29.8 & 0.1009 \\
\hline & 50.0 & 140.7 & -25.7 & 0.0719 \\
\hline & 55.0 & 139.2 & -27.7 & 0.0725 \\
\hline & 60.0 & 141.8 & -29.6 & 0.0577 \\
\hline \multirow[t]{14}{*}{$801 C-9$ R-1, 3} & 0.0 & 180.1 & 59.1 & 4.3636 \\
\hline & 2.5 & 194.9 & 50.4 & 3.7273 \\
\hline & 5.0 & 197.0 & 42.0 & 2.7909 \\
\hline & 10.0 & 199.0 & 35.9 & 1.5818 \\
\hline & 15.0 & 198.8 & 33.2 & 0.9455 \\
\hline & 20.0 & 199.9 & 32.3 & 0.6073 \\
\hline & 25.0 & 201.1 & 31.0 & 0.4282 \\
\hline & 30.0 & 202.4 & 31.6 & 0.3245 \\
\hline & 35.0 & 206.5 & 33.5 & 0.2255 \\
\hline & 40.0 & 199.2 & 32.1 & 0.1764 \\
\hline & 45.0 & 199.2 & 31.2 & 0.1455 \\
\hline & 50.0 & 208.5 & 38.0 & 0.1182 \\
\hline & 55.0 & 201.5 & 32.6 & 0.1100 \\
\hline & 60.0 & 202.0 & 34.0 & 0.0841 \\
\hline \multirow[t]{3}{*}{$801 \mathrm{C}-9 \mathrm{R}-1,130$} & 0.0 & 171.3 & 50.4 & 9.3636 \\
\hline & 2.5 & 170.3 & 45.1 & 7.7727 \\
\hline & 5.0 & 173.1 & 41.4 & 4.4909 \\
\hline
\end{tabular}


B. P. WALLICK, M. B. STEINER

APPENDIX (continued).

\begin{tabular}{|c|c|c|c|c|}
\hline $\begin{array}{l}\text { Sample } \\
(\mathrm{cm})\end{array}$ & $\begin{array}{c}\text { AF level } \\
(\mathrm{mT})\end{array}$ & $\begin{array}{l}\text { Declination } \\
\text { (degrees) }\end{array}$ & $\begin{array}{l}\text { Inclination } \\
\text { (degrees) }\end{array}$ & $\begin{array}{c}\text { Intensity } \\
(\mathrm{A} / \mathrm{m})\end{array}$ \\
\hline & 10.0 & 170.9 & 38.6 & 1.6909 \\
\hline & 15.0 & 171.0 & 38.1 & 0.9545 \\
\hline & 20.0 & 170.5 & 37.6 & 0.6718 \\
\hline & 25.0 & 171.4 & 36.8 & 0.5218 \\
\hline & 30.0 & 168.8 & 37.3 & 0.4282 \\
\hline & 35.0 & 167.2 & 38.8 & 0.3436 \\
\hline & 40.0 & 166.4 & 35.5 & 0.2673 \\
\hline & 45.0 & 171.1 & 36.8 & 0.2300 \\
\hline \multirow[t]{14}{*}{$801 \mathrm{C}-9 \mathrm{R}-2,31$} & 0.0 & 124.9 & 34.5 & 3.4727 \\
\hline & 2.5 & 145.8 & 44.1 & 2.4273 \\
\hline & 5.0 & 152.6 & 45.8 & 1.4091 \\
\hline & 10.0 & 154.3 & 40.4 & 0.6173 \\
\hline & 15.0 & 155.5 & 40.3 & 0.3918 \\
\hline & 20.0 & 157.1 & 40.0 & 0.2827 \\
\hline & 25.0 & 154.6 & 38.6 & 0.2200 \\
\hline & 30.0 & 160.3 & 35.6 & 0.1936 \\
\hline & 35.0 & 158.0 & 41.4 & 0.1455 \\
\hline & 40.0 & 156.2 & 40.5 & 0.1164 \\
\hline & 45.0 & 153.1 & 42.6 & 0.0876 \\
\hline & 50.0 & 155.8 & 34.9 & 0.0838 \\
\hline & 55.0 & 157.4 & 37.3 & 0.0612 \\
\hline & 60.0 & 148.2 & 44.0 & 0.0521 \\
\hline \multirow[t]{14}{*}{$801 C-9 R-3,26$} & 0.0 & 319.5 & 57.5 & 3.9182 \\
\hline & 2.5 & 322.2 & 53.2 & 2.7636 \\
\hline & 5.0 & 324.9 & 46.5 & 1.6636 \\
\hline & 10.0 & 324.4 & 40.6 & 0.8036 \\
\hline & 15.0 & 325.8 & 38.0 & 0.4836 \\
\hline & 20.0 & 327.1 & 39.8 & 0.3418 \\
\hline & 25.0 & 324.6 & 38.2 & 0.2600 \\
\hline & 30.0 & 330.2 & 34.9 & 0.2018 \\
\hline & 35.0 & 330.9 & 39.1 & 0.1855 \\
\hline & 40.0 & 326.4 & 36.7 & 0.1473 \\
\hline & 45.0 & 336.9 & 39.2 & 0.1164 \\
\hline & 50.0 & 333.5 & 35.8 & 0.1027 \\
\hline & 55.0 & 339.3 & 30.8 & 0.1009 \\
\hline & 60.0 & 338.1 & 31.2 & 0.0775 \\
\hline \multirow[t]{11}{*}{$801 C-9 R-3,117$} & 0.0 & 330.3 & 73.2 & 3.0727 \\
\hline & 2.5 & 344.9 & 71.1 & 2.2818 \\
\hline & 5.0 & 339.9 & 63.8 & 1.5455 \\
\hline & 10.0 & 335.2 & 55.2 & 0.6736 \\
\hline & 15.0 & 336.7 & 50.8 & 0.3145 \\
\hline & 20.0 & 336.0 & 48.9 & 0.1555 \\
\hline & 25.0 & 338.6 & 49.6 & 0.0873 \\
\hline & 30.0 & 346.1 & 41.4 & 0.0535 \\
\hline & 35.0 & 342.2 & 41.5 & 0.0373 \\
\hline & 40.0 & 338.3 & 49.5 & 0.0219 \\
\hline & 45.0 & 341.6 & 59.8 & 0.0184 \\
\hline \multirow[t]{8}{*}{$801 \mathrm{C}-9 \mathrm{R}-4,79$} & 0.0 & 245.6 & 81.7 & 4.0273 \\
\hline & 2.5 & 333.1 & 51.1 & 2.6273 \\
\hline & 5.0 & 331.8 & 42.7 & 1.5909 \\
\hline & 10.0 & 328.0 & 39.1 & 0.8127 \\
\hline & 20.0 & 328.9 & 36.8 & 0.3264 \\
\hline & 30.0 & 331.9 & 37.6 & 0.1682 \\
\hline & 40.0 & 329.7 & 37.3 & 0.1045 \\
\hline & 50.0 & 321.2 & 36.6 & 0.0515 \\
\hline \multirow[t]{10}{*}{$801 \mathrm{C}-10 \mathrm{R}-1,33$} & 0.0 & 245.1 & 52.1 & 4.0364 \\
\hline & 2.5 & 232.1 & 46.8 & 2.4182 \\
\hline & 5.0 & 230.0 & 42.8 & 1.3091 \\
\hline & 10.0 & 228.5 & 40.5 & 0.6209 \\
\hline & 20.0 & 233.5 & 42.6 & 0.2327 \\
\hline & 25.0 & 227.6 & 36.2 & 0.1718 \\
\hline & 30.0 & 219.4 & 43.9 & 0.1509 \\
\hline & 35.0 & 224.1 & 45.9 & 0.0878 \\
\hline & 40.0 & 221.2 & 26.2 & 0.0629 \\
\hline & 50.0 & 231.5 & 40.1 & 0.0419 \\
\hline \multirow[t]{6}{*}{$801 \mathrm{C}-10 \mathrm{R}-1,139$} & 0.0 & 128.3 & 71.2 & 5.0636 \\
\hline & 2.5 & 153.1 & 56.8 & 2.7364 \\
\hline & 5.0 & 155.9 & 50.4 & 1.5636 \\
\hline & 10.0 & 157.5 & 47.1 & 0.6745 \\
\hline & 15.0 & 157.6 & 46.5 & 0.3927 \\
\hline & 20.0 & 152.6 & 43.3 & 0.2682 \\
\hline
\end{tabular}

APPENDIX (continued).

\begin{tabular}{|c|c|c|c|c|}
\hline $\begin{array}{l}\text { Sample } \\
\text { (cm) }\end{array}$ & $\begin{array}{c}\text { AF level } \\
(\mathrm{mT})\end{array}$ & $\begin{array}{c}\text { Declination } \\
\text { (degrees) }\end{array}$ & $\begin{array}{l}\text { Inclination } \\
\text { (degrees) }\end{array}$ & $\begin{array}{c}\text { Intensity } \\
(\mathrm{A} / \mathrm{m})\end{array}$ \\
\hline & 25.0 & 158.0 & 45.4 & 0.1918 \\
\hline & 30.0 & 154.2 & 44.7 & 0.1645 \\
\hline & 35.0 & 145.9 & 45.5 & 0.1155 \\
\hline & 40.0 & 142.2 & 44.2 & 0.0891 \\
\hline & 45.0 & 142.1 & 52.6 & 0.0896 \\
\hline & 50.0 & 141.5 & 52.7 & 0.0594 \\
\hline & 55.0 & 140.4 & 48.4 & 0.0575 \\
\hline & 60.0 & 146.4 & 59.0 & 0.0582 \\
\hline \multirow[t]{14}{*}{$801 \mathrm{C}-10 \mathrm{R}-2,120$} & 0.0 & 24.3 & 57.7 & 1.9636 \\
\hline & 2.5 & 9.1 & 46.4 & 2.1636 \\
\hline & 5.0 & 8.4 & 41.9 & 1.6364 \\
\hline & 10.0 & 9.3 & 38.3 & 1.1364 \\
\hline & 15.0 & 9.9 & 37.8 & 0.8600 \\
\hline & 20.0 & 10.9 & 37.0 & 0.6555 \\
\hline & 25.0 & 9.6 & 37.6 & 0.5100 \\
\hline & 30.0 & 10.4 & 37.0 & 0.3991 \\
\hline & 35.0 & 10.4 & 36.4 & 0.3173 \\
\hline & 40.0 & 10.7 & 36.9 & 0.2545 \\
\hline & 45.0 & 7.8 & 36.7 & 0.2118 \\
\hline & 50.0 & 7.4 & 36.0 & 0.1700 \\
\hline & 55.0 & 4.9 & 31.4 & 0.1509 \\
\hline & 60.0 & 2.9 & 33.2 & 0.1245 \\
\hline \multirow[t]{14}{*}{$801 \mathrm{C}-10 \mathrm{R}-3,137$} & 0.0 & 107.4 & 34.6 & 10.8182 \\
\hline & 2.5 & 110.5 & 37.2 & 8.8545 \\
\hline & 5.0 & 108.0 & 36.1 & 5.5364 \\
\hline & 10.0 & 107.4 & 33.6 & 2.8091 \\
\hline & 15.0 & 107.7 & 33.2 & 1.8273 \\
\hline & 20.0 & 106.6 & 33.2 & 1.3636 \\
\hline & 25.0 & 107.6 & 33.6 & 1.0636 \\
\hline & 30.0 & 107.3 & 32.9 & 0.8700 \\
\hline & 35.0 & 106.0 & 30.8 & 0.7155 \\
\hline & 40.0 & 107.8 & 31.5 & 0.6009 \\
\hline & 45.0 & 106.2 & 32.8 & 0.5236 \\
\hline & 50.0 & 105.0 & 30.9 & 0.4418 \\
\hline & 55.0 & 105.4 & 32.5 & 0.3636 \\
\hline & 60.0 & 104.3 & 30.5 & 0.3245 \\
\hline \multirow[t]{14}{*}{$801 \mathrm{C}-10 \mathrm{R}-4,11$} & 0.0 & 99.8 & 45.7 & 8.8273 \\
\hline & 2.5 & 100.3 & 43.3 & 7.1545 \\
\hline & 5.0 & 100.0 & 42.0 & 4.9818 \\
\hline & 10.0 & 100.2 & 41.1 & 2.9727 \\
\hline & 15.0 & 100.4 & 40.1 & 2.1000 \\
\hline & 20.0 & 100.3 & 41.3 & 1.6273 \\
\hline & 25.0 & 100.7 & 41.0 & 1.3273 \\
\hline & 30.0 & 99.2 & 40.9 & 1.1000 \\
\hline & 35.0 & 99.4 & 40.8 & 0.9182 \\
\hline & 40.0 & 99.1 & 40.7 & 0.7673 \\
\hline & 45.0 & 97.6 & 40.5 & 0.6664 \\
\hline & 50.0 & 97.2 & 41.2 & 0.5745 \\
\hline & 55.0 & 98.5 & 42.2 & 0.4782 \\
\hline & 60.0 & 101.0 & 42.5 & 0.4327 \\
\hline \multirow[t]{14}{*}{$801 \mathrm{C}-10 \mathrm{R}-4,58$} & 0.0 & 288.7 & 56.0 & 3.3909 \\
\hline & 2.5 & 322.3 & 40.1 & 2.6455 \\
\hline & 5.0 & 321.1 & 39.5 & 1.8364 \\
\hline & 10.0 & 318.4 & 38.8 & 0.9182 \\
\hline & 15.0 & 317.7 & 39.8 & 0.5218 \\
\hline & 20.0 & 317.0 & 37.0 & 0.3400 \\
\hline & 25.0 & 316.5 & 39.2 & 0.2509 \\
\hline & 30.0 & 323.8 & 36.3 & 0.1900 \\
\hline & 35.0 & 329.4 & 36.6 & 0.1482 \\
\hline & 40.0 & 319.7 & 36.8 & 0.1109 \\
\hline & 45.0 & 319.9 & 26.4 & 0.1091 \\
\hline & 50.0 & 325.7 & 33.0 & 0.0918 \\
\hline & 55.0 & 327.8 & 28.5 & 0.0851 \\
\hline & 60.0 & 333.7 & 34.0 & 0.0683 \\
\hline \multirow[t]{8}{*}{$801 C-10 R-4,114$} & 0.0 & 53.4 & 40.7 & 0.8936 \\
\hline & 2.5 & 348.0 & 63.1 & 0.6509 \\
\hline & 5.0 & 334.3 & 55.1 & 0.3509 \\
\hline & 10.0 & 329.6 & 48.9 & 0.1491 \\
\hline & 15.0 & 336.5 & 46.6 & 0.0784 \\
\hline & 20.0 & 319.7 & 38.2 & 0.0626 \\
\hline & 25.0 & 321.1 & 33.1 & 0.0434 \\
\hline & 30.0 & 305.3 & 36.3 & 0.0391 \\
\hline
\end{tabular}


APPENDIX (continued).

\begin{tabular}{|c|c|c|c|c|}
\hline $\begin{array}{c}\text { Sample } \\
(\mathrm{cm})\end{array}$ & $\begin{array}{c}\text { AF level } \\
(\mathrm{mT})\end{array}$ & $\begin{array}{c}\text { Declination } \\
\text { (degrees) }\end{array}$ & $\begin{array}{l}\text { Inclination } \\
\text { (degrees) }\end{array}$ & $\begin{array}{c}\text { Intensity } \\
(\mathrm{A} / \mathrm{m})\end{array}$ \\
\hline & 35.0 & 313.7 & 24.2 & 0.0253 \\
\hline & 40.0 & 2.4 & 50.0 & 0.0366 \\
\hline & 45.0 & 333.3 & 51.2 & 0.0227 \\
\hline & 55.0 & 304.4 & 10.6 & 0.0249 \\
\hline & 60.0 & 293.9 & 28.8 & 0.0160 \\
\hline \multirow[t]{11}{*}{$801 \mathrm{C}-10 \mathrm{R}-5,122$} & 0.0 & 34.2 & 76.5 & 1.6273 \\
\hline & 2.5 & 73.9 & 73.2 & 0.7945 \\
\hline & 5.0 & 64.0 & 65.1 & 0.3900 \\
\hline & 10.0 & 70.6 & 37.6 & 4.5818 \\
\hline & 15.0 & 44.0 & 52.8 & 0.0760 \\
\hline & 20.0 & 48.5 & 45.9 & 0.0467 \\
\hline & 25.0 & 23.8 & 31.1 & 0.0422 \\
\hline & 30.0 & 49.2 & 12.0 & 0.0270 \\
\hline & 35.0 & 37.0 & 31.6 & 0.0166 \\
\hline & 40.0 & 57.8 & 27.9 & 0.0199 \\
\hline & 45.0 & 50.3 & 54,4 & 0.0227 \\
\hline \multirow[t]{9}{*}{$801 \mathrm{C}-10 \mathrm{R}-6,7$} & 0.0 & 301.9 & 31.2 & 1.7636 \\
\hline & 2.5 & 300.4 & 53.6 & 0.8845 \\
\hline & 5.0 & 300.5 & 49.3 & 0.4436 \\
\hline & 10.0 & 315.2 & 42.5 & 0.1764 \\
\hline & 15.0 & 312.4 & 39.9 & 0.0927 \\
\hline & 20.0 & 313.8 & 44.7 & 0.0732 \\
\hline & 25.0 & 323.4 & 47.2 & 0.0384 \\
\hline & 30.0 & 344.2 & 27.0 & 0.0298 \\
\hline & 35.0 & 4.5 & 10.5 & 0.0167 \\
\hline \multirow[t]{10}{*}{$801 C-10 R-6,95$} & 0.0 & 218.1 & 38.7 & 2.9636 \\
\hline & 2.5 & 232.0 & 41.9 & 2.2364 \\
\hline & 5.0 & 251.6 & 44.1 & 1.2909 \\
\hline & 10.0 & 266.6 & 31.5 & 0.6564 \\
\hline & 15.0 & 273.6 & 40.6 & 0.1900 \\
\hline & 20.0 & 278.7 & 37.9 & 0.1018 \\
\hline & 25.0 & 284.3 & 43.0 & 0.0596 \\
\hline & 30.0 & 285.5 & 38.6 & 0.0383 \\
\hline & 35.0 & 280.0 & 38.4 & 0.0260 \\
\hline & 40.0 & 287.6 & 33.4 & 0.0169 \\
\hline \multirow[t]{10}{*}{$801 C-11 R-1,9$} & 0.0 & 207.0 & -21.3 & 2.3455 \\
\hline & 2.5 & 195.0 & -21.7 & 2.1182 \\
\hline & 5.0 & 190.7 & -22.2 & 1.5182 \\
\hline & 10.0 & 188.9 & -22.5 & 0.4936 \\
\hline & 15.0 & 185.6 & -22.4 & 0.1836 \\
\hline & 20.0 & 183.8 & -20.6 & 0.0982 \\
\hline & 25.0 & 182.8 & -21.1 & 0.0584 \\
\hline & 30.0 & 180.2 & -24.4 & 0.0394 \\
\hline & 35.0 & 181.1 & -24.8 & 0.0265 \\
\hline & 40.0 & 177.9 & -20.0 & 0.0215 \\
\hline \multirow[t]{8}{*}{$801 C-11 R-1,36$} & 0.0 & 82.8 & 40.9 & 1.2636 \\
\hline & 2.5 & 96.5 & 52.2 & 0.9182 \\
\hline & 5.0 & 102.8 & 51.4 & 0.5227 \\
\hline & 10.0 & 119.1 & 47.2 & 0.1473 \\
\hline & 15.0 & 125.3 & 50.3 & 0.0532 \\
\hline & 20.0 & 119.9 & 53.7 & 0.0252 \\
\hline & 25.0 & 112.3 & 48.6 & 0.0160 \\
\hline & 30.0 & 110.5 & 33.7 & 0.0096 \\
\hline \multirow[t]{11}{*}{$801 \mathrm{C}-11 \mathrm{R}-1,100$} & 0.0 & 332.5 & 69.8 & 1.5545 \\
\hline & 2.5 & 329.1 & 41.8 & 0.9636 \\
\hline & 5.0 & 323.1 & 32.1 & 0.5773 \\
\hline & 10.0 & 318.8 & 18.3 & 0.2291 \\
\hline & 15.0 & 315.9 & 15.6 & 0.1291 \\
\hline & 20.0 & 311.9 & 19.6 & 0.0721 \\
\hline & 25.0 & 315.7 & 14.5 & 0.0434 \\
\hline & 30.0 & 319.4 & 5.4 & 0.0330 \\
\hline & 35.0 & 299.2 & 11.6 & 0.0156 \\
\hline & 40.0 & 351.5 & -38.5 & 0.0095 \\
\hline & 45.0 & 292.9 & -72.5 & 0.0121 \\
\hline \multirow[t]{6}{*}{$801 C-11 R-2,22$} & 0.0 & 308.5 & 69.7 & 2.9909 \\
\hline & 2.5 & 309.4 & 64.9 & 2.1909 \\
\hline & 5.0 & 322.5 & 61.7 & 1.1182 \\
\hline & 10.0 & 331.0 & 34.8 & 0.4118 \\
\hline & 15.0 & 335.9 & 23.4 & 0.2136 \\
\hline & 25.0 & 329.6 & 19.7 & 0.1418 \\
\hline
\end{tabular}

APPENDIX (continued).

\begin{tabular}{|c|c|c|c|c|}
\hline $\begin{array}{l}\text { Sample } \\
\text { (cm) }\end{array}$ & $\begin{array}{l}\text { AF level } \\
(\mathrm{mT})\end{array}$ & $\begin{array}{c}\text { Declination } \\
\text { (degrees) }\end{array}$ & $\begin{array}{l}\text { Inclination } \\
\text { (degrees) }\end{array}$ & $\begin{array}{c}\text { Intensity } \\
(\mathrm{A} / \mathrm{m})\end{array}$ \\
\hline & 30.0 & 333.0 & 10.7 & 0.0867 \\
\hline & 35.0 & 318.6 & 15.5 & 0.0633 \\
\hline & 40.0 & 331.8 & 19.1 & 0.0547 \\
\hline & 45.0 & 331.8 & 17.9 & 0.0511 \\
\hline & 50.0 & 335.1 & 13.9 & 0.0344 \\
\hline \multirow[t]{12}{*}{$801 C-11 R-2,48$} & 0.0 & 184.9 & 46.8 & 6.5455 \\
\hline & 2.5 & 184.2 & 43.9 & 5.7273 \\
\hline & 5.0 & 185.0 & 42.3 & 3.8727 \\
\hline & 10.0 & 183.4 & 40.5 & 1.5818 \\
\hline & 15.0 & 183.3 & 40.2 & 0.7991 \\
\hline & 20.0 & 183.4 & 39.7 & 0.4873 \\
\hline & 25.0 & 182.7 & 40.5 & 0.3164 \\
\hline & 30.0 & 180.9 & 40.1 & 0.2000 \\
\hline & 35.0 & 181.7 & 40.0 & 0.1300 \\
\hline & 40.0 & 184.0 & 38.4 & 0.0845 \\
\hline & 45.0 & 181.0 & 31.3 & 0.0568 \\
\hline & 50.0 & 185.2 & 28.5 & 0.0265 \\
\hline \multirow[t]{13}{*}{$801 C-11 R-2,139$} & 0.0 & 82.1 & -10.8 & 13.2727 \\
\hline & 2.5 & 82.3 & -11.2 & 13.0000 \\
\hline & 5.0 & 82.3 & -12.1 & 11.4545 \\
\hline & 10.0 & 82.3 & -12.8 & 6.2182 \\
\hline & 15.0 & 82.5 & -13.2 & 3.2273 \\
\hline & 20.0 & 81.9 & -13.4 & 1.8818 \\
\hline & 25.0 & 82.4 & -13.4 & 1.1455 \\
\hline & 30.0 & 82.2 & -12.5 & 0.7355 \\
\hline & 35.0 & 81.6 & -13.2 & 0.4855 \\
\hline & 40.0 & 81.9 & -10.3 & 0.3173 \\
\hline & 45.0 & 83.2 & -7.5 & 0.2273 \\
\hline & 50.0 & 81.2 & -4.9 & 0.1555 \\
\hline & 55.0 & 86.0 & -1.0 & 0.1118 \\
\hline \multirow[t]{14}{*}{$801 \mathrm{C}-11 \mathrm{R}-3,52$} & 0.0 & 51.4 & -9.9 & 1.7545 \\
\hline & 2.5 & 53.1 & -12.7 & 1.6818 \\
\hline & 5.0 & 53.3 & -15.1 & 1.5182 \\
\hline & 10.0 & 56.5 & -21.6 & 1.0818 \\
\hline & 15.0 & 57.5 & -24.1 & 0.7000 \\
\hline & 20.0 & 58.3 & -25.2 & 0.4455 \\
\hline & 25.0 & 58.1 & -25.6 & 0.2827 \\
\hline & 30.0 & 57.6 & -25.9 & 0.1791 \\
\hline & 35.0 & 56.2 & -25.7 & 0.1227 \\
\hline & 40.0 & 54.8 & -25.4 & 0.0828 \\
\hline & 45.0 & 49.8 & -24.3 & 0.0606 \\
\hline & 50.0 & 43.7 & -24.5 & 0.0451 \\
\hline & 55.0 & 38.2 & -21.5 & 0.0371 \\
\hline & 60.0 & 30.8 & -25.5 & 0.0298 \\
\hline \multirow[t]{13}{*}{$801 \mathrm{C}-11 \mathrm{R}-3,140$} & 0.0 & 341.9 & 38.3 & 0.3882 \\
\hline & 2.5 & 338.6 & 39.5 & 0.3245 \\
\hline & 5.0 & 348.3 & 40.6 & 0.2764 \\
\hline & 10.0 & 348.3 & 26.6 & 0.0927 \\
\hline & 15.0 & 346.9 & -10.6 & 0.0395 \\
\hline & 20.0 & 359.7 & -0.8 & 0.0264 \\
\hline & 25.0 & 24.4 & -13.4 & 0.0154 \\
\hline & 30.0 & 57.9 & -22.7 & 0.0141 \\
\hline & 35.0 & 68.8 & -14.3 & 0.0180 \\
\hline & 40.0 & 72.6 & -21.1 & 0.0184 \\
\hline & 45.0 & 73.2 & -18.0 & 0.0233 \\
\hline & 50.0 & 75.3 & -25.3 & 0.0244 \\
\hline & 55.0 & 78.8 & -20.4 & 0.0256 \\
\hline \multirow[t]{10}{*}{$801 \mathrm{C}-12 \mathrm{R}-1,37$} & 0.0 & 316.5 & -36.8 & 0.6218 \\
\hline & 2.5 & 316.4 & -40.3 & 0.5691 \\
\hline & 5.0 & 315.6 & -46.4 & 0.4864 \\
\hline & 10.0 & 298.0 & -45.1 & 0.2691 \\
\hline & 15.0 & 297.8 & -45.4 & 0.1191 \\
\hline & 20.0 & 298.2 & -48.2 & 0.0591 \\
\hline & 25.0 & 296.5 & -58.7 & 0.0274 \\
\hline & 30.0 & 291.7 & -68.2 & 0.0155 \\
\hline & 30.0 & 291.7 & -68.2 & 0.0155 \\
\hline & 35.0 & 264.3 & -83.6 & 0.0125 \\
\hline \multirow[t]{4}{*}{$801 \mathrm{C}-12 \mathrm{R}-1,107$} & 0.0 & 57.0 & -23.3 & 0.6518 \\
\hline & 2.5 & 65.7 & -20.2 & 0.5091 \\
\hline & 5.0 & 89.8 & -18.3 & 0.4264 \\
\hline & 10.0 & 98.4 & -27.7 & 0.1527 \\
\hline
\end{tabular}


APPENDIX (continued).

\begin{tabular}{|c|c|c|c|c|}
\hline $\begin{array}{l}\text { Sample } \\
\text { (cm) }\end{array}$ & $\begin{array}{l}\text { AF level } \\
(\mathrm{mT})\end{array}$ & $\begin{array}{l}\text { Declination } \\
\text { (degrees) }\end{array}$ & $\begin{array}{l}\text { Inclination } \\
\text { (degrees) }\end{array}$ & $\begin{array}{c}\text { Intensity } \\
(\mathrm{A} / \mathrm{m})\end{array}$ \\
\hline & 15.0 & 103.7 & -30.9 & 0.0730 \\
\hline & 20.0 & 106.5 & -28.7 & 0.0397 \\
\hline & 25.0 & 67.4 & -64.0 & 0.0255 \\
\hline & 30.0 & 105.7 & -51.7 & 0.0129 \\
\hline & 35.0 & 143.0 & -39.0 & 0.0112 \\
\hline & 40.0 & 113.3 & -37.5 & 0.0116 \\
\hline \multirow[t]{13}{*}{$801 \mathrm{C}-12 \mathrm{R}-1,144$} & 0.0 & 18.6 & 38.3 & 0.5700 \\
\hline & 2.5 & 36.1 & 36.7 & 0.3618 \\
\hline & 5.0 & 53.3 & 32.4 & 0.2600 \\
\hline & 10.0 & 87.9 & 10.1 & 0.1073 \\
\hline & 15.0 & 93.6 & -1.2 & 0.0646 \\
\hline & 20.0 & 98.5 & 2.1 & 0.0367 \\
\hline & 25.0 & 105.6 & 5.6 & 0.0234 \\
\hline & 30.0 & 122.4 & 2.6 & 0.0192 \\
\hline & 35.0 & 136.2 & 8.7 & 0.0138 \\
\hline & 40.0 & 146.7 & -19.1 & 0.0151 \\
\hline & 45.0 & 156.0 & -11.2 & 0.0154 \\
\hline & 50.0 & 162.7 & 1.8 & 0.0142 \\
\hline & 55.0 & 177.1 & -30.8 & 0.0172 \\
\hline \multirow[t]{9}{*}{$801 C-12 \mathrm{R}-2,42$} & 0.0 & 172.2 & 25.7 & 0.6000 \\
\hline & 2.5 & 354.9 & 11.6 & 0.2100 \\
\hline & 5.0 & 347.1 & -10.4 & 0.1818 \\
\hline & 10.0 & 355.2 & -16.9 & 0.0874 \\
\hline & 15.0 & 5.5 & -27.2 & 0.0452 \\
\hline & 20.0 & 3.1 & -24.9 & 0.0259 \\
\hline & 25.0 & 16.5 & -23.1 & 0.0128 \\
\hline & 30.0 & 358.8 & -40.2 & 0.0066 \\
\hline & 35.0 & 44.7 & -15.9 & 0.0066 \\
\hline \multirow[t]{14}{*}{$801 C-12 R-2,134$} & 0.0 & 334.9 & 51.5 & 3.5091 \\
\hline & 2.5 & 5.4 & 24.3 & 1.5909 \\
\hline & 5.0 & 7.0 & -16.8 & 1.6000 \\
\hline & 10.0 & 6.4 & -29.5 & 1.2091 \\
\hline & 15.0 & 7.3 & -32.6 & 0.9455 \\
\hline & 20.0 & 8.2 & -33.9 & 0.7345 \\
\hline & 25.0 & 6.5 & -34.7 & 0.5755 \\
\hline & 30.0 & 6.3 & -34.5 & 0.4618 \\
\hline & 35.0 & 5.1 & -36.7 & 0.3500 \\
\hline & 40.0 & 9.0 & -33.7 & 0.2827 \\
\hline & 45.0 & 6.7 & -31.5 & 0.2318 \\
\hline & 50.0 & 12.3 & -32.4 & 0.1945 \\
\hline & 55.0 & 14.1 & -33.6 & 0.1782 \\
\hline & 60.0 & 6.4 & -35.3 & 0.1482 \\
\hline
\end{tabular}

